\title{
LEGITIMIDADE E RESPONSABILIDADE DO JUDICIÁRIO EM UM AMBIENTE DEMOCRÁTICO
}

\author{
Eurípedes Gomes Faim Filho ${ }^{1}$
}

\section{INTRODUÇÃO}

Este estudo tratará da legitimidade e responsabilidade do Poder Judiciário e de seus membros em um ambiente democrático.

Essa questão se mostra atual e relevante porque há uma noção difundida na opinião pública, nos centros de Poder e até nos meios acadêmicos mais refinados de que o Judiciário carece de legitimidade democrática e seus membros gozam de injusta impunidade por seus atos.

A demonstrar essa afirmação temos a recente aprovação no Senado
Federal da Proposta de Emenda Constitucional $n^{\circ} 89 / 2003$, sobre a qual comentaremos no momento oportuno.

Para analisar isso, em primeiro lugar, tentaremos dar uma ideia breve dos conceitos de poder e democracia para, em seguida, questionarmos se o Judiciário é um poder do Estado, se é democraticamente legítimo e qual a possibilidade de o Judiciário ser um construtor de políticas públicas.

Depois, veremos sucintamente as limitações e os controles existentes para o exercício da judicatura, para, finalmente, entrarmos na questão da responsabilidade, fazendo uma com-

1 Professor, mestre e doutor pela Faculdade de Direito do Largo de São Francisco da Universidade de São Paulo (USP). Professor do Curso de Pós-Graduação da Escola Superior do Ministério Público do Estado de São Paulo e da Escola Paulista da Magistratura do Tribunal de Justiça do Estado de São Paulo. Ex-professor da Faculdade de Direito da UNESP em Franca e de outras. Magistrado paulista desde 1989, ora em Entrância Final. Membro do Núcleo de Planejamento e Gestão do Tribunal de Justiça do Estado de São Paulo por dois mandatos. 
paração da responsabilidade que têm o Judiciário e seus componentes com relação aos demais Poderes e seus membros.

A responsabilidade política por crimes de responsabilidade será a primeira a ser enfrentada, seguida da responsabilidade fiscal do Judiciário e as outras responsabilidades de seus membros, ou seja, a civil, a penal, a administrativa, a relativa a "erros jurídicos" e outra responsabilidade que consideramos relevante.

Definido isso, discutiremos quais os deveres do Estado no caso de erro judiciário.

Esperamos, dessa forma, dentro das nossas evidentes limitações, oferecer subsídios para tão relevante discussão.

\section{PODER E DEMOCRACIA}

A definição prévia, mesmo que breve, de "poder" e de "democracia" é necessária para uma melhor compreensão deste estudo.

Poder é a possibilidade de tomar decisões que influenciem na esfera de terceiros, com ou sem o consentimento desses, e a democracia é a forma pela qual o poder é exercido com variados graus de participação popular. ${ }^{2}$

Manoel Ferreira diz, com razão, que a ideia de que só é legítimo o governo que provenha do povo é um dogma mundialmente unânime, sendo "tabu a discussão dos méritos ou deméritos da democracia". ${ }^{3}$

Democracia, no ensinamento de Manoel Ferreira, ${ }^{4}$ não tem um conceito unívoco podendo-se falar em democracia direta, como a praticada na Atenas de Péricles, em democracia semidireta, que esse professor entende ser modalidade da representativa, $\mathrm{e}$ em democracia indireta representativa, oriunda das revoluções modernas $\mathrm{e}$, segundo esse mestre, do horror à plebe que tinha Siéyès.

Não passaram despercebidas a Manoel Ferreira as falhas da ideia de mandato na representação política, posto que o representante político não está adstrito às instruções do mandante, nem pode ser por ele destituído ou substituído e nem ao menos presta contas a ele, salvo em termos morais. ${ }^{5}$

2 SILVA, José Afonso da. Curso de Direito Constitucional Positivo. 33. ed. p. 106-107. São Paulo: Malheiros, 2010.

3 FERREIRA Filho, Manoel Gonçalves. Curso de Direito Constitucional. 32. ed. Sobre o tabu, p. 101. Sobre os demais temas tratados nesta seção por Manoel Ferreira, p. 98 e seguintes. São Paulo: Saraiva, 2006.

4 Obra citada, p. 79 e seguintes.

5 Obra citada, p. 85. 
Aqui convém lembrar que o representante eleito pode pura e simplesmente não concorrer a nova eleição, razão de ser verdade a afirmação do mestre Manoel Ferreira de que não há prestação de contas ou responsabilidade perante o povo, salvo a moral, advinda de promessas inviáveis de se cumprir, dada à sua generalidade e abstração, o que ele menciona ao tratar de partidos políticos.

Esse tipo de governo, segundo Manoel Ferreira, baseia-se em dois valores que lhe servem de inspiração: a liberdade e a igualdade. Mas os conceitos de liberdade e igualdade não encontram um sentido inequívoco, como ocorre com o conceito de democracia, dependendo seu entendimento da orientação política de cada um.

Relaciona Manoel Ferreira como pressupostos da democracia os seguintes:

1. O pressuposto social (os povos têm que ter maturidade para se governarem).

2. O pressuposto econômico (os povos não podem estar preocupados apenas com a sobrevivência).

3. O pressuposto informativo (o povo precisa de informação abundante, não monopolizada e contraditória).

4. O pressuposto das amplas liberdades públicas (tais como o direito de reunião, de associação, de manifestação, entre outros).

5. O pressuposto do sistema eleitoral (a existência de uma forma de obter e computar a vontade popular livre de fraudes e corrupções).

Vejamos agora a questão de o Judiciário ser ou não um poder do Estado e se ele tem ou não legitimidade democrática.

\section{O JUDICIÁRIO COMO PODER DO ESTADO}

A doutrina francesa via de regra não admite o Judiciário como um poder do Estado, daí a estranha expressão, para nós, do título da obra de Fabrice Hourquebie quando ele fala do judiciário como "anti-poder" ("contre-pouvoir"). ${ }^{6}$

De fato, o Poder estatal tem como características fundamentais a "unidade, indivisibilidade e indelegabilidade, de onde parecer impróprio

6 HOURQUEBIE, Fabrice. Sur l'émergence du Contre-pouvoir Juridictionnel sous La $V^{e ̀ m e}$ République. Bruxelles: Bruylant, 2004. 
falar-se em divisão e delegação de poderes" devendo-se concluir que o Poder é único, havendo uma divisão de funções dentro do seu exercício. ${ }^{7}$

Como alerta Manoel Ferreira, a função jurisdicional aproxima-se da função administrativa e com ela se confunde quando se trata de aplicar a lei ao caso concreto, havendo diferença apenas na forma de atuação e no resultado da atuação. Assim é que o Judiciário não deve agir de ofício, mas apenas quando houver lide, provocação e o devido processo legal com estabelecimento do contraditório, ao contrário, via de regra, do Executivo, o qual normalmente pode agir de ofício e independente de lide. Além disso, as decisões do Judiciário revestem-se do manto da coisa julgada, o que impede sua rediscussão, também diversamente do que ocorre com o Executivo. ${ }^{8}$

Contudo, hoje, a função jurisdicional se amplia no Brasil para incluir lides coletivas e até para inovar no campo do Direito, o que discutiremos melhor ao tratarmos do Judiciário como construtor de políticas públicas.
A Constituição de 1988, seguindo nossa tradição, colocou o Poder Judiciário como um Poder do Estado:

Art. $2^{\circ}$ São Poderes da União, independentes e harmônicos entre si, o Legislativo, o Executivo e o Judiciário. (Grifo nosso.)

Por sua vez, o Supremo Tribunal Federal afirmou o Judiciário como componente do Poder do Estado no Brasil:

[...] Os antigos regimentos lusitanos não se confundem com os regimentos internos dos Tribunais; de comum eles têm apenas o nome. Aqueles eram variantes legislativas da monarquia absoluta, enquanto estes resultam do fato da elevação do Judiciário a Poder do Estado e encontram no Direito Constitucional seu fundamento e sua previsão expressa. $\mathbf{O}$ ato do julgamento é o momento culminante da ação jurisdicional do Poder Judiciário e há de ser regulado em seu regimento interno, com exclusão de interferência dos demais Poderes. (ADI 1.105-MC, Rel. Min. Paulo Brossard, julgamento em 3-81994, Plenário, DJ de 27-4- 2001.) (Grifo nosso.) ${ }^{9}$

7 SILVA, José Afonso da. Obra citada, p. 107.

8 FERREIRA Filho, Manoel Gonçalves. Obra citada, p. 245-246.

9 Nesse sentido: RIBEIRO, Antônio de Pádua. O Judiciário como Poder Político no Século XXI. In: Boletim da Faculdade de Direito. Stvdia Ivridica 40, Colloqquia 2. p. 11 a 26. "Portugal - Brasil Ano 2000. Tema Direito". Universidade de Coimbra. Coimbra: Coimbra, 1999. 
Mas o Supremo Tribunal Federal alerta sobre a existência do sistema de freios e contrapesos, com mecanismos de controle recíproco entre os Poderes, ou, melhor dizendo, funções do Poder do Estado, porém na forma da Constituição:

Separação e independência dos Poderes: freios e contrapesos: parâmetros federais impostos ao Estado-membro. Os mecanismos de controle recíproco entre os Poderes, os "freios e contrapesos" admissíveis na estruturação das unidades federadas, sobre constituírem matéria constitucional local, só se legitimam na medida em que guardem estreita similaridade com os previstos na Constituição da República: precedentes. Consequente plausibilidade da alegação de ofensa do princípio fundamental por dispositivos da Lei estadual 11.075/1998-RS (inciso IX do art. $2^{\circ}$ e arts. 33 e 34 ), que confiam a organismos burocráticos de segundo e terceiro graus do Poder Executivo a função de ditar parâmetros e avaliações do funcionamento da Justiça [...].” (ADI 1.905MC, Rel. Min. Sepúlveda Pertence, julgamento em 19-11-1998, Plenário, $D J$ de 5-11-2004.) (Grifo nosso.)

A Constituição de 1988 não apenas colocou o Poder Judiciário como um Poder do Estado, mas também deu a ele a função de seu guardião, sendo o guarda máximo da Constituição o Supremo Tribunal Federal, por isso Uadi Bulos chama o Judiciário de o "oráculo da Constituição."10

$\mathrm{O}$ dispositivo que colocou o Judiciário como guarda máximo da Constituição diz:

Art. 102. Compete ao Supremo Tribunal Federal, precipuamente, a guarda da Constituição, cabendolhe: [...]. (Grifo nosso.)

Sobre a condição de guardião máximo da Constituição, decidiu o Supremo Tribunal Federal:

A defesa da Constituição da República representa o encargo mais relevante do Supremo Tribunal Federal. O Supremo Tribunal Federal - que é o guardião da Constituição, por expressa delegação do Poder Constituinte - não pode renunciar ao exercício desse encargo, pois, se a Suprema Corte falhar no desempenho da gravíssima atribuição que lhe foi outorgada, a integridade do sistema político, a proteção das liberdades públicas, a estabilidade do ordenamento normativo do Estado, a segurança das relações jurídicas e a legitimidade das instituições da República restarão profundamente comprometidas. $\mathrm{O}$ inaceitável desprezo pela Constituição não pode converter-se em prática governamental consentida. Ao menos, enquanto houver um Poder Ju-

10 BULOS, Uadi Lammêgo. Curso de Direito Constitucional. p. 1.041. São Paulo: Saraiva, 2007. 
diciário independente e consciente de sua alta responsabilidade política, social e jurídico-institucional. (ADI 2.010-MC, Rel. Min. Celso de Mello, julgamento em 30-9-99, Plenário, $D J$ de 12.4.02). (Grifo nosso.)

Esse julgado agora mencionado tem especial relevância para o presente estudo ao reconhecer as responsabilidades que tem o Judiciário.

Porém, convém ponderar neste momento o problema da legitimidade democrática do Judiciário, questionamento que surge do fato de que seus membros não são eleitos, e é o que passamos a fazer.

\section{LEGITIMIDADE DEMOCRÁTICA DO PODER JUDICIÁRIO}

A legitimidade democrática é estabelecida pelo Poder Constituinte Originário por meio de sistemas de escolha daqueles que comporão os Poderes Constituídos, havendo nesse processo maior ou menor participação popular por meio do voto.

Assim é que a escolha do Poder Executivo no Brasil é feita por elei- ções com grande participação popular, mas os governantes acabam sendo escolhidos com a exclusão de quase metade dos votantes, além da exclusão de mais da metade da população do país, se forem considerados os que não votam.

Não bastasse isso, uma campanha custa muito caro e a influência do Poder Econômico é inegável e maior, sem dúvida, do que o poder do voto do cidadão, além do que as pessoas, via de regra, decidem votar de acordo com imagens de marketing montadas por caríssimos especialistas no assunto.

Também, muitas vezes, realizamse campanhas com a prática reiterada e desavergonhada de crimes eleitorais, propositadamente dotados de punições muito brandas ou inexequíveis, com completo desprezo pela ética e pela moral, não apenas pelo Direito.

Curioso que nos Estados Unidos da América, país considerado uma das maiores democracias do mundo, nem sempre o mais votado pelo povo é aquele que se torna o Presidente da República, em virtude do sistema lá adotado. $^{11}$

O Poder Legislativo brasileiro padece de um déficit democrático pelo

11 Tais fatos se deram nas eleições de 1876, 1824 (John Quincy Adans obteve menos votação popular e menos votação no Colégio Eleitoral, mas mesmo assim foi o eleito pela Câmara dos Deputados); 1888, e 2000 (o candidato Al Gore obteve 543.895 votos populares a mais que o candidato George Bush, mas este último ganhou no Colégio Eleitoral). Disponível em: <http://www.archives.gov/federal-register/electoral-college/ historical.html >. Acessado em: 26.08.2010. 
menos igual ao do Poder Executivo. Como é de todos sabido, a composição da Câmara dos Deputados, à qual competiria representar o povo, é formada usando-se um complexo cálculo por meio do qual se chega ao chamado coeficiente eleitoral, ou seja, os votos do partido é que contam, quando na verdade o cidadão votou no candidato.

Curioso que, mesmo com esse sistema, como alerta Mônica Caggiano, a infidelidade partidária é a regra, havendo uma verdadeira "dança das cadeiras" entre nossos políticos, na feliz expressão por ela usada. ${ }^{12}$

Tal sistema permite distorções totalmente disparatadas como as que ocorreram nas eleições de 2002 em que o candidato do partido Prona, Enéas Carneiro, obteve um número astronômico de votos, todos contados para seu partido e repartidos entre os candidatos do partido. Isso levou a ser teoricamente eleito, por exemplo, o candidato Tocera, ${ }^{13}$ sem que ele tivesse recebido absolutamente nenhum voto popular, enquanto candidatos bem votados não foram eleitos, não havendo, portanto, verdadeira representação integral da vontade popular na formação do parlamento.
Além disso, embora a Constituição diga no seu art. 45 que a Câmara dos Deputados representa o povo, tal não ocorre devido ao fato de que há um mínimo e um máximo de deputados por Estado-membro, cujo cálculo é regulado pela Lei Complementar 78/1993.

Conforme se pode apurar no site do Tribunal Superior Eleitoral (www. tse.jus.br), por exemplo, em abril de 2008 o Estado do Acre contava com $0,33 \%$ do total do eleitorado nacional enquanto que o Estado de São Paulo detinha $22,47 \%$ desse total. Dessa forma, se valesse a regra democrática que dispõe que uma pessoa vale um voto, São Paulo deveria ter 113 deputados, já o Acre não mais do que dois.

Contudo, São Paulo tem apenas 70 deputados e o Acre, oito, o que faz com que o voto do eleitor do Acre seja quatro vezes mais valioso que o voto do eleitor paulista, estando demonstrada, assim, outra grave falha na teoria da representatividade democrática do Poder Legislativo federal.

A escolha dos componentes do Poder Judiciário, finalmente, também é feita como a dos demais, ou seja, por um sistema estabelecido pelo Poder

12 A Jurisprudência Constitucional sobre Matéria Eleitoral. Disponível em: $<\mathrm{http}: / /$ www.mackenzie.br/fileadmin/Graduacao/FDir/Artigos_2008/Controle_de_consti_2008_processo_constitucional_publ_mackenzie.pdf $>$. Acessado em: 26.08.2010.

13 Informação disponível em: <http://forum.jus.uol.com.br/12170/candidato-eleito-sem-votos/>. Acessado em: 18 de maio de 2010. 
Constituinte Originário. Nesse sistema também há participação popular, pois, teoricamente, o povo elegeu o Constituinte Originário e os componentes do Poder Legislativo e Executivo, os quais participam da escolha de magistrados ou da elaboração de leis para esse fim. ${ }^{14}$

Disso tudo se conclui que os três Poderes da República têm legitimidade democrática, cada um de acordo com o sistema que o Poder Constituinte escolheu para o Poder em questão. ${ }^{15}$

Questão em voga no momento, ligada à legitimidade, diz respeito ao Judiciário como construtor de políti- cas públicas, questão que também é conhecida como o problema do ativismo judiciário, o qual passa-se a analisar.

\section{O JUDICIÁRIO COMO CONSTRUTOR DE POLÍTICAS PÚBLICAS}

Como alerta Lawrence Baum, mesmo quando o Judiciário age como legislador negativo haveria de certa forma ativismo judiciário, com interferência desse Poder em políticas públicas estabelecidas pelos demais. ${ }^{16}$

14 Nesse sentido, também entendendo que a legitimidade vem da Constituição, vide DALlARI, Dalmo de Abreu. O poder dos Juizes. 2. ed. p. 89. São Paulo: Saraiva, 2002.

A respeito de eleição direta de magistrados pelo povo, Daniel A. Sabsay e José M. Onaindia afirmam que a eleição popular, embora praticada em alguns países no passado e atualmente, não é o sistema mais indicado para tal escolha devido ao fato de que submete os magistrados a lutas partidárias e à exigência de sua clientela eleitoral. ( $\mathrm{La}$ Constitucion de Los Argentinos. 3. ed., p. 376. Buenos Aires: Errapar, 1994.)

15 Renato Nalini fundamenta a legitimação do juiz concursado nos seguintes pilares: 1 . Mérito; 2. Fundamentação das decisões; 3. Cumprimento de sua missão constitucional. (A Rebelião da Toga. p. 44-48. Campinas: Millennium, 2006.)

Alexandre de Moraes, lembrando Otto Bachof, também afirma a legitimidade do Judiciário, lembrando que, como ele, os demais Poderes também têm representatividade indireta e relativa. (Constituição do Brasil Interpreta e Legislação Constitucional. 7. ed., p. 1.319. São Paulo: Atlas, 2007.)

Em sentido contrário, entendendo pela ausência de legitimidade democrática do Poder Judiciário vide: LEAL, Roger Stiefelmann. A Judicialização da Política. In: Revista dos Tribunais. Cadernos de Direito Constitucional e Ciência Política. Instituto Brasileiro de Direito Constitucional número 29, p. 230-237, outubro/dezembro de 1999.

16 A Suprema Corte Americana. p. 260 e seguintes. Rio de Janeiro: Forense Universitária, 1987. 
Ilustrando essa questão de interferência em políticas públicas pelo Judiciário como legislador negativo, Jonh Nowak e Ronald Rotunda ${ }^{17}$ noticiam a resistência enorme ocorrida na Suprema Corte norte-americana quando da instituição do "New Deal" pelo Presidente Roosevelt, a qual quase destruiu o plano como um todo.

Por fim, a posição do Presidente Roosevelt prevaleceu porque, em 1937, ele elaborou o seu "Court Packing Plan", o qual, se tivesse sido aprovado, elevaria o número de ministros da Suprema Corte para quinze, e só não o foi porque os próprios ministros alteraram sua posição aprovando o "New Deal".

Outro caso, foi a política da instituição do imposto sobre a renda, impedida pela Suprema Corte e só conseguida após a aprovação da décima sexta emenda à Constituição dos
Estados Unidos da América, como informam os mesmos autores. ${ }^{18}$

No Brasil, em inúmeros julgados, o Supremo Tribunal Federal tem reafirmado a posição de legislador negativo e não positivo que deve tomar o Judiciário para evitar invasão de um Poder na esfera de outro. ${ }^{19}$

Mas, em se tratando de matéria em que a Constituição estabeleceu reserva de lei formal, o Supremo Tribunal Federal foi até mais incisivo:
A reserva de lei constitui postula- do revestido de função excludente, de caráter negativo, pois veda, nas matérias a ela sujeitas, quaisquer intervenções normativas, a título primário, de órgãos estatais não legislativos. Essa cláusula consti- tucional, por sua vez, projeta-se em uma dimensão positiva, eis que a sua incidência reforça o princípio, que, fundado na autoridade da Constitui- ção, impõe, à administração e à ju-

17 Constitutional Law. 4. ed. p. 150-151. Saint Paul: West Publishing, 1991.

18 Obra citada, p. 188.

19 [...] O STF como legislador negativo: A ação direta de inconstitucionalidade não pode ser utilizada com o objetivo de transformar o STF, indevidamente, em legislador positivo, eis que o poder de inovar o sistema normativo, em caráter inaugural, constitui função típica da instituição parlamentar. [...] (ADI 1.063-MC-QO, Rel. Min. Celso de Mello, julgamento em 18-5-1994, Plenário, DJ de 27-4-2001.) No mesmo sentido: AI 360.461-AgR, 2005; ADI 267-MC, 1995; ADI 1.949-MC, 2005; ADI 267-MC, 1995; MS 22.690, 2006; ADPF 144, 2010; ADI 1.949-MC, 2005; ADI 1.063-MC-QO, 2001; RE 584.315-AgR, 2008; ADI 1.502-MC, 1996; RE 402.748-AgR; RE 418.994-AgR, 2008; RE 410.515-AgR, 2009; RE 347.079-AgR, 2008; AI 142.348-AgR, 1995; ADI 1.755, 2001; MS 22.690, 2006; MS 22.690, 2006; RE 584.315-AgR, 2008; ADI 1.502MC, 1996; RE 402.748-AgR; RE 418.994-AgR, 2008; RE 410.515-AgR, 2009; RE 347.079-AgR, 2008; AI 142.348-AgR, 1995; ADI 1.949-MC, 2005; ADI 1.063-MCQO, 2001; RE 402.748-AgR; RE 418.994-AgR, 2008; RE 410.515-AgR, 2009. 
risdição, a necessária submissão aos comandos estatais emanados, exclusivamente, do legislador. Não cabe, ao Poder Judiciário, em tema regido pelo postulado constitucional da reserva de lei, atuar na anômala condição de legislador positivo $(R T J$ 126/48 - RTJ 143/57 - RTJ 146/461462 - RTJ 153/765, v.g.), para, em assim agindo, proceder à imposição de seus próprios critérios, afastando, desse modo, os fatores que, no âmbito de nosso sistema constitucional, só podem ser legitimamente definidos pelo Parlamento. É que, se tal fosse possível, o Poder Judiciário - que não dispõe de função legislativa passaria a desempenhar atribuição que lhe é institucionalmente estranha (a de legislador positivo), usurpando, desse modo, no contexto de um sistema de poderes essencialmente limitados, competência que não lhe pertence, com evidente transgressão ao princípio constitucional da separação de poderes. (MS 22.690, Rel. Min. Celso de Mello, julgamento em 17.4.1997, Plenário, DJ de 7.12.2006.) (Grifo nosso.)

Entretanto, o Supremo não tem aceitado desrespeito à Constituição, de forma alguma:

A autoridade hierárquico-normativa da Constituição da República impõe-se a todos os Poderes do Estado. Nenhuma razão - nem mesmo a invocação do princípio do autogoverno da Magistratura - pode justificar o desrespeito à Constituição. Ninguém tem o direito de subordinar o texto constitucional à conveniência dos interesses de grupos, de corporações ou de classes, pois o desprezo pela Constituição faz instaurar um perigoso estado de insegurança jurídica, além de subverter, de modo inaceitável, os parâmetros que devem reger a atuação legítima das autoridades constituídas. (ADI 2.105-MC, Rel. Min. Celso de Mello, julgamento em 23.3.00, Plenário, $D J$ de 28.4.00.) (Grifo nosso.)

A invocação das razões de Estado - além de deslegitimar-se como fundamento idôneo de justificação de medidas legislativas - representa, por efeito das gravíssimas consequências provocadas por seu eventual acolhimento, uma ameaça inadmissível às liberdades públicas, à supremacia da ordem constitucional e aos valores democráticos que a informam, culminando por introduzir, no sistema de direito positivo, um preocupante fator de ruptura e de desestabilização político jurídica. Nada compensa a ruptura da ordem constitucional. Nada recompõe os gravíssimos efeitos que derivam do gesto de infidelidade ao texto da Lei Fundamental. A defesa da Constituição não se expõe, nem deve submeter-se, a qualquer juízo de oportunidade ou de conveniência, muito menos a avaliações discricionárias fundadas em razões de pragmatismo governamental. A relação do Poder e de seus agentes, com a Constituição, há de ser, necessariamente, uma relação de respeito. Se, em determinado momento histórico, circunstâncias de fato ou de direito reclamarem a alteração da Constituição, em ordem 
a conferir-lhe um sentido de maior contemporaneidade, para ajustá-la, desse modo, às novas exigências ditadas por necessidades políticas, sociais ou econômicas, impor-se-á a prévia modificação do texto da Lei Fundamental, com estrita observância das limitações e do processo de reforma estabelecidos na própria Carta Política. [...] (ADI 2.010-MC, Rel. Min. Celso de Mello, julgamento em 30-9-99, Plenário, $D J$ de 12.4.02.) (Grifo nosso.)

Em se tratando de norma autoaplicável o Supremo Tribunal Federal não se furta à sua função:

Após ouvir os depoimentos prestados pelos representantes dos diversos setores envolvidos, entendo ser necessário redimensionar a questão da judicialização do direito à saúde no Brasil. Isso porque, na maioria dos casos, a intervenção judicial não ocorre em razão de uma omissão absoluta em matéria de políticas públicas voltadas à proteção do direito à saúde, mas tendo em vista uma necessária determinação judicial para o cumprimento de políticas já estabelecidas. Portanto, não se cogita do problema da interferência judicial em âmbitos de livre apreciação ou de ampla discricionariedade de outros Poderes quanto à formulação de políticas públicas. Esse dado pode ser importante para a construção de um critério ou parâmetro para a decisão em casos como este, no qual se discute, primordialmente, o problema da interferência do Poder Judiciário na esfera dos outros Poderes. O primeiro dado a ser considerado é a existência, ou não, de política estatal que abranja a prestação de saúde pleiteada pela parte. Ao deferir uma prestação de saúde incluída entre as políticas sociais e econômicas formuladas pelo Sistema Único de Saúde (SUS), o Judiciário não está criando política pública, mas apenas determinando o seu cumprimento. Nesses casos, a existência de um direito subjetivo público a determinada política pública de saúde parece ser evidente. Se a prestação de saúde pleiteada não estiver entre as políticas do SUS, é imprescindível distinguir se a não prestação decorre de uma omissão legislativa ou administrativa, de uma decisão administrativa de não fornecê-la ou de uma vedação legal a sua dispensação. ${ }^{20}$ (Grifo nosso.)

Merece menção ainda as palavras do Ministro Celso de Melo proferidas quando do julgamento do STA 175AgR/CE no dia 17 de março de 2010:

20 Brasília, 7 de abril de 2010. Ministro GILMAR MENDES Presidente (SS 4045, Relator(a): Min. Presidente, Decisão Proferida pelo(a) Ministro(a) GILMAR MENDES, julgado em: 07/04/2010, publicado em DJe-066 DIVULG 14/04/2010 PUBLIC 15/04/2010). 
O desprestígio da Constituição - por inércia de órgãos meramente constituídos - representa um dos mais graves aspectos da patologia constitucional, pois reflete inaceitável desprezo, por parte das instituições governamentais, da autoridade suprema da Lei Fundamental do Estado.

Dessa forma, se a política pública já foi criada pela própria Constituição, cabe ao Judiciário aplicá-la:

Embora resida, primariamente, nos Poderes Legislativo e Executivo, a prerrogativa de formular e executar políticas públicas, revela-se possível, no entanto, ao Poder Judiciário, determinar, ainda que em bases excepcionais, especialmente nas hipóteses de políticas públicas definidas pela própria Constituição, sejam estas implementadas pelos órgãos estatais inadimplentes, cuja omissão - por importar em descumprimento dos encargos político-jurídicos que sobre eles incidem em caráter mandatório - mostra-se apta a comprometer a eficácia e a integridade de direitos sociais e culturais impregnados de estatura constitucional. A questão pertinente à "reserva do possível". (RE 436.996-AgR, Rel. Min. Celso de Mello, julgamento em 22.11.05, $2^{\mathrm{a}}$ Turma, DJ de 3-2-06). No mesmo sentido: RE 464.143-AgR, Rel. Min. Ellen Gracie, julgamento em 15.12.09, $2^{\text {a }}$ Turma, DJE de 19.2.10; RE 595.595-AgR, Rel. Min. Eros
Grau, julgamento em 28.4.09, $2^{\mathrm{a}}$ Turma, DJE de 29.5.09.

Salientou ainda o Supremo Tribunal Federal um sistema de mutação constitucional muito utilizado na $\mathrm{Su}$ prema Corte norte-americana:

A interpretação judicial como instrumento de mutação informal da Constituição. A questão dos processos informais de mutação constitucional e o papel do Poder Judiciário: a interpretação judicial como instrumento juridicamente idôneo de mudança informal da Constituição. A legitimidade da adequação, mediante interpretação do Poder Judiciário, da própria Constituição da República, se e quando imperioso compatibilizá-la, mediante exegese atualizadora, com as novas exigências, necessidades e transformações resultantes dos processos sociais, econômicos e políticos que caracterizam, em seus múltiplos e complexos aspectos, a sociedade contemporânea. (HC 91.361, Rel. Min. Celso de Mello, julgamento em 23.9.08, $2^{\mathrm{a}}$ Turma, DJE de 6.2.09. $)^{21}$ (Grifo nosso.)

Assim é que nos Estados Unidos da América a Constituição tem mais de duzentos anos de idade, mas vem sendo constantemente atualizada pela interpretação dada a ela pela Suprema Corte no decorrer dos anos.

21 Nesse sentido: FERRAZ, Anna Cândida da Cunha. Processos Informais de Mudança da Constituição. Sem local: Max Limonad, 1986. 
No Brasil, na verdade, nos aproximamos cada vez mais do sistema de Common Law nos últimos anos, também conhecido como sistema do "judge made Law". Tal sistema, ao contrário do que mitologicamente se crê, não se baseia no costume, mas sim no precedente e na legislação escrita, e é a nova força do precedente que nos aproxima desse sistema. ${ }^{22}$

Maria Sylvia menciona que o Brasil adotou um sistema de jurisdição una, próprio do Common Law, embora não adotando o stare deci$s i s,{ }^{23}$ não dando poder vinculante à jurisprudência, mas sofrendo grande influência do sistema constitucional Norte-americano. ${ }^{24}$

Ocorre que, em 1993, o sistema jurídico brasileiro sofreu uma profunda mudança introduzida pela Emenda Constitucional $\mathrm{n}^{\mathrm{o}} 3$, que acrescentou o $\S 2^{\circ}$ ao art. 102 da Constituição da República:

Art. $102[\ldots] \S 2^{\circ}-$ As decisões definitivas de mérito, proferidas pelo Supremo Tribunal Federal, nas ações declaratórias de constitucionalidade de lei ou ato normativo federal, produzirão eficácia contra todos e

22 Conforme JAMES, Philip S. Introduction to English Law. Twelfth Edition. p. 7 e passim. London: Butteerworths, 1989. A força do precedente é enorme, como informa o mesmo autor: " $[\ldots]$ In the legislative sphere Parliament is thus legally 'sovereign' and master, but this does not mean that the courts have no influence upon the development of enacted law; for, in order to be applied, every enactment, however it be promulgated, has to be interpreted (or construed), and the courts are the recognized interpreters of the law. [...]" (p. 8).

23 "A doutrina do Stare decisis na cultura jurídica dos Estados Unidos simplesmente significa que uma vez que a Corte de última instância no sistema judiciário federal ou estadual decida um princípio de direito para o caso em julgamento, estabelecendo assim um precedente, a Corte continuará a aderir a este precedente, aplicando-o a casos futuros em que os fatos relevantes sejam substancialmente os mesmos, ainda que as partes não sejam as mesmas. Portanto, 'precedente' é a regra jurídica usada pela Corte de última instância no local em que o caso foi decidido, aplicado aos fatos relevantes que criaram a questão de mérito levada perante a Corte para decisão. Stare decisis é a política que exige que as Cortes subordinadas à Corte de última instância que estabelece o precedente sigam aquele precedente, e 'não mudem uma questão decidida'. Este princípio, aplicando a doutrina do stare decisis para estabelecer precedente vinculante, veio para a cultura jurídica dos Estados Unidos da tradição do common law inglês." COLE, Charles D. Stare Decisis na Cultura Jurídica dos Estados Unidos. O Sistema de Precedente Vinculante do Common Law. In: Revista dos Tribunais, Fascículo Cível, Ano 87, V. 752, junho de 1998, p. 11-21.

24 DI PIETRO, Maria Sylvia Z. Direito Administrativo. 19. ed. p. 44-45. São Paulo: Atlas, 2006. 
efeito vinculante relativamente aos demais órgãos do Poder Judiciário e ao Poder Executivo. (Grifo nosso.)

Surgiu, assim, o precedente vinculante, somente para as ações declaratórias de constitucionalidade, o que fez com que de Europeu Continental o nosso sistema passasse a ser híbrido com o sistema do Common Law.

A característica do sistema Europeu Continental é ter a lei escrita como fonte primária e obrigatória do direito e, a jurisprudência, como fonte secundária não obrigatória. Já no sistema do Common Law, o precedente, ou seja, a jurisprudência, é vinculante, isto é, tão obrigatório quanto a lei.

Logo depois veio a lei $n^{\circ}$ 9868/99 que ampliou o precedente vinculante também para as ações diretas de inconstitucionalidade:

Artigo 28 parágrafo único "a declaração de constitucionalidade ou de inconstitucionalidade, inclusive a interpretação conforme a constituição e a declaração parcial de inconstitucionalidade sem redução de texto, tem eficácia contra todos e efeito vinculante em relação aos órgãos do poder judiciário e à administração pública federal, estadual e municipal. (Grifo nosso.)

A doutrina discutiu muito essa ampliação, por não ter sido feita por via de emenda constitucional, ${ }^{25}$ mas em 2002 o STF, ao apreciar uma questão de ordem na reclamação 1880 , ajuizada pelo município paulista de Turmalina, considerou constitucional esse dispositivo. ${ }^{26}$

Finalmente, em dezembro de 2004, tal preceito foi colocado expressamente na Constituição com a redação dada ao art. $102, \S 2^{\circ}$, pela Emenda Constitucional $n^{\circ} 45$ :

Art. $102 \S 2^{\circ}$ As decisões definitivas de mérito, proferidas pelo Supremo Tribunal Federal, nas ações diretas de inconstitucionalidade e nas ações declaratórias de constitucionalidade produzirão eficácia contra todos e efeito vinculante relativamente aos demais órgãos do Poder Judiciário e à administração pública direta e indireta, nas esferas federal, estadual e municipal. (Grifo nosso.)

25 Conforme ARAÚJO, Luiz Alberto David; NUNES JÚNIOR, Vidal Serrano. Curso de Direito Constitucional. 11. ed. p. 48-49. São Paulo: Saraiva, 2007.

26 EMENTA: [...] 1. É constitucional lei ordinária que define como de eficácia vinculante os julgamentos definitivos de mérito proferidos pelo Supremo Tribunal Federal em ação direta de inconstitucionalidade (Lei 9868/99, artigo 28, parágrafo único). 2. [...] (Rcl 1880 AgR, Relator(a): Min. MAURÍCIO CORRÊA, Tribunal Pleno, julgado em: 07/11/2002, DJ 19-03-2004 PP-00017 EMENT VOL-02144-02 PP-00284). (Grifo nosso.) 
Também pela mesma emenda foi criada a súmula vinculante, prevista no art. 103-A da Constituição da República.

A diferença entre o precedente e a súmula é a formalidade maior da súmula e o fato de que essa seria fruto do controle difuso e aquele do concentrado.

Para que o precedente exista é suficiente que o Supremo Tribunal Federal, numa ação direta de inconstitucio- nalidade ou em uma ação declaratória de constitucionalidade, pronuncie-se uma única vez pela constitucionalidade ou não de uma dada norma.

A súmula vinculante, por sua vez, exige reiteradas decisões sobre matéria constitucional, ${ }^{27}$ que é o que ocorre no sistema difuso, além de uma série de formalidades para ser considerada aprovada como se vê nos parágrafos do art. 103-A da Constituição da República. ${ }^{28}$

27 O Ex-Presidente do STF, Ministro Gilmar Mendes, na obra que escreveu em conjunto com Inocêncio Coelho e Paulo Branco, afirma na p. 916 "Outro requisito para edição da súmula vinculante refere-se à preexistência de reiteradas decisões sobre matéria constitucional." (Curso de Direito Constitucional. São Paulo: Saraiva, 2007.) Contudo, a Súmula Vinculante número 11 foi elaborada com base em apenas quatro acórdãos, um deles redigido na vigência da Constituição anterior, sendo um pouco duvidosa a conclusão extraída deles e que deu origem à súmula (RHC 56.456-8/SP. Relator Cordeiro Guerra. 5 de setembro de 1978; HC 71195-2/SP. Relator Ministro Francisco Rezek. 25.10.1994; HC 89429-1/RO. Relatora Ministra Cármen Lúcia. 22.08.2006; e HC 91.952-9/SP. Relator Ministro Marco Aurélio. 07.08.2008). Diz a Súmula: "Só é lícito o uso de algemas em casos de resistência e de fundado receio de fuga ou de perigo à integridade física própria ou alheia, por parte do preso ou de terceiros, justificada a excepcionalidade por escrito, sob pena de responsabilidade disciplinar, civil e penal do agente ou da autoridade e de nulidade da prisão ou do ato processual a que se refere, sem prejuízo da responsabilidade civil do Estado".

28 Constituição da República: Art. 103-A. O Supremo Tribunal Federal poderá, de ofício ou por provocação, mediante decisão de dois terços dos seus membros, após reiteradas decisões sobre matéria constitucional, aprovar súmula que, a partir de sua publicação na imprensa oficial, terá efeito vinculante em relação aos demais órgãos do Poder Judiciário e à administração pública direta e indireta, nas esferas federal, estadual e municipal, bem como proceder à sua revisão ou ao seu cancelamento, na forma estabelecida em lei. (Incluído pela Emenda Constitucional $n^{\circ} 45$, de 2004.) (Vide Lei $\mathrm{n}^{\circ} 11.417$, de 2006.) $\S 1^{\circ} \mathrm{A}$ súmula terá por objetivo a validade, a interpretação e a eficácia de normas determinadas, acerca das quais haja controvérsia atual entre órgãos judiciários ou entre esses e a administração pública que acarrete grave insegurança jurídica e relevante multiplicação de processos sobre questão idêntica. $\S 2^{\circ}$ Sem prejuízo do que vier a ser estabelecido em lei, a aprovação, a revisão ou o cancelamento de súmula poderão ser provocados por aqueles que podem propor a ação direta de 
Assim, em termos de Direito brasileiro hoje é fonte primária do Direito:

1. A lei escrita, como sempre foi.

2. Os precedentes nas ações declaratórias de constitucionalidade, desde 1993.

3. Os precedentes nas ações diretas de inconstitucionalidade, desde 1999.

4. As súmulas vinculantes do Supremo Tribunal Federal, desde 2004.

Curioso, como ensina Alexandre de Moraes, que essa ideia de adaptação do sistema de stare decisis por meio da súmula vinculante não é nova, pois já fora adotada no Império em 1876 quando o Superior Tribunal de Justiça passou a ter a possibilidade de editar assentos com força de lei. ${ }^{29}$

A jurisprudência tem sido crescentemente prestigiada também por normas infraconstitucionais, podendo ser citados a título de exemplo o caso da chamada súmula impeditiva de recurso $^{30}$ e o afastamento do reexame necessário quando o magistrado de Primeiro Grau julgar de acordo com súmula, ${ }^{31}$ entre outros.

Além desse ganho de força da jurisprudência, a atuação judicial se mostra ativa no combate à inconstitucionalidade por omissão. A intolerância com o desrespeito à Constituição por omissão já foi iniciada pelo Constituinte que introduziu no nosso sistema o mandado de injunção e a ação de inconstitucionalidade por omissão para combatê-la. ${ }^{32}$

inconstitucionalidade. $\S 3^{\circ}$ Do ato administrativo ou decisão judicial que contrariar a súmula aplicável ou que indevidamente a aplicar, caberá reclamação ao Supremo Tribunal Federal que, julgando-a procedente, anulará o ato administrativo ou cassará a decisão judicial reclamada, e determinará que outra seja proferida com ou sem a aplicação da súmula, conforme o caso.

29 Direito Constitucional. 19. ed. p. 514. São Paulo: Atlas, 2006.

30 Código de Processo Civil: Art. $518 \S 1$ O juiz não receberá o recurso de apelação quando a sentença estiver em conformidade com súmula do Superior Tribunal de Justiça ou do Supremo Tribunal Federal.

31 Código de Processo Civil: Art. 475. Está sujeita ao duplo grau de jurisdição, não produzindo efeito senão depois de confirmada pelo tribunal, a sentença: [...] § $3^{\circ}$ Também não se aplica o disposto neste artigo quando a sentença estiver fundada em jurisprudência do plenário do Supremo Tribunal Federal ou em súmula deste Tribunal ou do tribunal superior competente.

32 André Ramos Tavares registrou frustração com relação às expectativas depositadas nesse instrumento constitucional por uma posição mais tímida do Supremo Tribunal Federal (Curso de Direito Constitucional. 5. ed. p. 296-297. São Paulo: Saraiva, 2007. 
Entendemos que o Judiciário só poderá sanar essas omissões, em se tratando de políticas públicas, se houver na Constituição e na lei parâmetros suficientes para estabelecer tal política, como tem reconhecido o Supremo Tribunal Federal na sua árdua tarefa de proteger a Constituição, inclusive dos negligentes.

Avaliada a importante questão da legitimidade do Poder Judiciário, já é possível discutir os limites da atuação desse Poder e a responsabilidade que dela decorre para ele e seus membros.

\section{AS LIMITAÇÕES E OS CONTROLES AO EXERCÍCIO DO PODER PELO JUDICIÁRIO}

Fabrice Hourquebie ${ }^{33}$ menciona em sua obra vários mecanismos de controle da função jurisdicional, todos eles incorporados pelo nosso sistema constitucional na sua declaração de direitos fundamentais e pelas leis infraconstitucionais.
Lembramos que as declarações de direito não têm qualquer significado se não houver um meio dentro do sistema do Estado para torná-las realidade e para amparar seu titular quando sofrer abusos ou tiver seus direitos contrariados. Tal meio são as chamadas garantias pelas quais se procura tornar reais as declarações de direitos, por meio de um Judiciário independente, como disse o Ministro Gilmar Mendes do Supremo Tribunal Federal:

Concordo, subscrevo e assino os abaixo-assinados da Ajufe, da AMB e de todas as associações internacionais a favor da independência do Judiciário. Eu já disse que a independência judicial é mais importante que catálogo de direitos fundamentais. ${ }^{34}$

Essas garantias não são apenas vias processuais adequadas para defesa de direitos, mas também uma série de princípios essenciais que podemos listar como sendo os seguintes, entre outros:

\footnotetext{
Alexandre de Moraes salientou que o objetivo do Constituinte era, por esse instrumento, dar plena validade às normas constitucionais. (Direito Constitucional. 19. ed., p. 696. São Paulo: Atlas, 2006.)
}

33 HOURQUEBIE, Fabrice. Obra citada, passim.

34 Disponível em: <http://www.stf.jus.br/portal/cms/verNoticiaDetalhe.asp?idConteudo $=100199 \&$ tip $=\mathrm{UN}>$. Acessado em: 13.05.2010. 
1. Princípio da inafastabilidade da jurisdição, não podendo a lei criar obstáculos não amparados na Constituição ao acesso à Jurisdição. ${ }^{35}$

2. A exigência de haver um Poder Judiciário livre e independente e compromissado com o cumprimento da Constituição e das leis que forem constitucionais.

3. Princípio do juiz natural, consagrado nos incisos LIII e XXXVII do art. $5^{\circ}$ da Constituição. ${ }^{36}$

4. Princípio do devido processo legal, o qual é previsto em quatro incisos do art. $5^{\circ}$ da Constituição da República, ${ }^{37}$ oriundo do Direito Inglês e do Direito Norte-Americano e que, para ser realidade, exige uma série de outros requisitos: a) A existência de um juiz imparcial;

b) A impossibilidade de o juiz agir de ofício;

c) A necessidade de se reconhecer que o juiz só pode dar ordens jurisdicionais $^{38}$ dentro de um processo regularmente formado e processado na forma da lei;

d) A necessidade do contraditório;

e) A necessidade de ampla defesa;

f) A necessidade de haver pelo menos um recurso.

O processo penal, pela sua peculiaridade de lidar com a liberdade do ser humano, tem uma série de princípios especiais previstos na Constituição:

1. Princípio da presunção de inocência. ${ }^{39}$

35 Art. $5^{\circ}$ XXXV - a lei não excluirá da apreciação do Poder Judiciário lesão ou ameaça a direito; [...].

36 Art. $5^{\circ}$ LIII - ninguém será processado nem sentenciado senão pela autoridade competente; Art. $5^{\circ}$ XXXVII - não haverá juízo ou tribunal de exceção; [...].

37 Art. $5^{\circ}$ LIV - ninguém será privado da liberdade ou de seus bens sem o devido processo legal; Art. $5^{\circ} \mathrm{LV}$ - aos litigantes, em processo judicial ou administrativo, e aos acusados em geral são assegurados o contraditório e a ampla defesa, com os meios e recursos a ela inerentes; Art. $5^{\circ} \mathrm{LX}$ - a lei só poderá restringir a publicidade dos atos processuais quando a defesa da intimidade ou o interesse social o exigirem; Art. $5^{\circ}$ LXXIV - o Estado prestará assistência jurídica integral e gratuita aos que comprovarem insuficiência de recursos; [...].

38 Ordens de natureza administrativa, no exercício da função atípica, podem ser dadas por portarias, provimentos, ordens de serviço, assentos, regimentos etc.

39 Art. $5^{\circ}$ LVII - ninguém será considerado culpado até o trânsito em julgado de sentença penal condenatória; [...]. 
2. Princípio de que o identificado civilmente não precisa sofrer identificação criminal. ${ }^{40}$

3. A possibilidade de haver ação penal privada subsidiária da pública no caso de inércia do Ministério Público. ${ }^{41}$

4. A instituição do júri, com todas as suas consequências. ${ }^{42}$

Há, ainda no campo penal, os direitos do preso:

1. Só pode haver dois tipos de prisão: em flagrante ou por ordem escrita da autoridade judiciária competente, salvo a exceção prevista na Constituição. ${ }^{43}$ Entram como or- dem escrita as denominadas prisões civis, como é o caso do devedor de alimentos e do depositário infiel, essa última hoje vedada pela Súmula Vinculante 25 do Supremo Tribunal Federal. ${ }^{44}$

2. Toda prisão deve ser imediatamente comunicada ao juiz competente, bem como à família do preso ou a quem ele indicar $^{45}$ e o juiz, percebendo a ilegalidade da prisão, de pronto concederá habeas corpus de ofício, mandando soltar o preso, ${ }^{46}$ razão de serem mantidos plantões judiciários em todos os fins de semana e feriados, sem interrupção.

40 Art. $5^{\circ}$ LVIII - o civilmente identificado não será submetido à identificação criminal, salvo nas hipóteses previstas em lei; [...].

41 Art. $5^{\circ}$ LIX - será admitida ação privada nos crimes de ação pública, se esta não for intentada no prazo legal; [...].

42 Art. $5^{\circ}$ XXXVIII - é reconhecida a instituição do júri, com a organização que lhe der a lei, assegurados: a) a plenitude de defesa; b) o sigilo das votações; c) a soberania dos veredictos; d) a competência para o julgamento dos crimes dolosos contra a vida; [...]. 43 Art. $5^{\circ}$ LXI - ninguém será preso senão em flagrante delito ou por ordem escrita e fundamentada de autoridade judiciária competente, salvo nos casos de transgressão militar ou crime propriamente militar, definidos em lei; [...].

44 Art. $5^{\circ}$ LXVII - não haverá prisão civil por dívida, salvo a do responsável pelo inadimplemento voluntário e inescusável de obrigação alimentícia e a do depositário infiel; [...].

Súmula Vinculante 25 - É ilícita a prisão civil de depositário infiel, qualquer que seja a modalidade do depósito.

45 Art. $5^{\circ}$ LXII - a prisão de qualquer pessoa e o local onde se encontre serão comunicados imediatamente ao juiz competente e à família do preso ou à pessoa por ele indicada; $[. .$.$] .$

46 Art. $5^{\circ} \mathrm{LXV}$ - a prisão ilegal será imediatamente relaxada pela autoridade judiciária; $[\ldots]$. 
3. A prisão, como algo excepcional que é, não deve ser mantida se for possível a concessão da liberdade provisória. ${ }^{47}$

4. O preso deve ser cientificado de seus direitos. ${ }^{48}$

5. O preso deve ser informado sobre quem o está prendendo ou interrogando. ${ }^{49}$

$\mathrm{Na}$ verdade, toda lei processual civil ou penal consiste em limites ao exercício da jurisdição, mas uma análise mais profunda disso extrapola o âmbito deste trabalho.

A par dos mencionados limites, várias normas estabelecem responsabilidades para o Judiciário e seus membros, o que seguimos vendo.

\section{A RESPONSABILIDADE COMO PRESSUPOSTO DO PODER NA DEMOCRACIA}

A responsabilidade não é elencada como pressuposto do exercício do poder democrático como vimos anteriormente, mas ela está a ele ligada devido ao valor da liberdade, inspirador da ideia de democracia, como dito acima.

Assim é que Elena Tãnãsecu ${ }^{50}$ lembra que a responsabilidade nada mais é que outra face da liberdade, significando a liberdade a possibilidade de atuar sem coerção. Ela ensina que a responsabilidade está ligada à relação do indivíduo com a comunidade e envolve a consciência e o cuidado do agente em relação a suas próprias ações e às consequências delas.

A ação irresponsável repugna ao Direito, tendo o Ministro Celso de Melo do Supremo Tribunal Federal dito que "a responsabilidade dos juízes: [é] uma expressão do postulado republicano", ${ }^{51}$ razão de discutirmos tal questão no âmbito do Poder Judiciário, cuja importância "avulta, se o olharmos sob o prisma das liberdades e direitos individuais, de que é a primeira e principal garantia." 52 (Grifo nosso.)

47 Art. $5^{\circ}$ LXVI - ninguém será levado à prisão ou nela mantido, quando a lei admitir a liberdade provisória, com ou sem fiança; [...].

48 Art. $5^{\circ}$ LXIII - o preso será informado de seus direitos, entre os quais o de permanecer calado, sendo-lhe assegurada a assistência da família e de advogado; [...].

49 Art. $5^{\circ} \mathrm{LXIV}$ - o preso tem direito à identificação dos responsáveis por sua prisão ou por seu interrogatório policial; [...].

50 TÃNÃSECU, Elena Simina. p. 2. On Responsibility in Public Law.

$51 \mathrm{MS}$ 28.801-MC/DF. 02.08.2010.

52 Manoel Ferreira, obra citada, p. 243. 


\section{A RESPONSABILIDADE POLÍTICA DO JUDICIÁRIO - CRIMES DE RESPONSABILIDADE}

\begin{abstract}
Dispõe a Constituição da República Art. 52. Compete privativamente ao Senado Federal: [...].

II. processar e julgar os Ministros do Supremo Tribunal Federal, os membros do Conselho Nacional de Justiça e do Conselho Nacional do Ministério Público, o Procurador-Geral da República e o Advogado-Geral da União nos crimes de responsabilidade; [...]. (Redação dada pela Emenda Constitucional $n^{\circ} 45$, de 2004.) (Grifo nosso.)
\end{abstract}

Como se vê, à semelhança do que ocorre com o Presidente da República, os Ministros do Supremo Tribunal Federal e os Conselheiros do Conselho Nacional de Justiça respondem politicamente perante o Senado $\mathrm{Fe}$ deral.

Os Ministros dos tribunais superiores também respondem por crimes de natureza política, mas já perante $o$ Supremo Tribunal Federal:

Art. 102. Compete ao Supremo Tribunal Federal, precipuamente, a guarda da Constituição, cabendo-lhe: I-processar e julgar, originariamente: $[\ldots]$ c) nas infrações penais comuns e nos crimes de responsabilidade, os Ministros de Estado e os Comandantes da Marinha, do Exército e da Aeronáutica, ressalvado o disposto no art. 52, I, os membros dos Tribunais Superiores, os do Tribunal de Contas da União e os chefes de missão diplomática de caráter permanente; [...] (Redação dada pela Emenda Constitucional no 23, de 1999). (Grifo nosso.)

Convém lembrar aqui que além de o Direito Penal ser matéria de competência legislativa exclusiva da União, ${ }^{53}$ o Supremo Tribunal Federal entendeu que a ampliação da possibilidade do impeachment para outras autoridades estaduais sem correspondente federal não é constitucionalmente viável:

Os dispositivos impugnados contemplam a possibilidade de a Assembleia Legislativa capixaba convocar o Presidente do Tribunal de Justiça para prestar, pessoalmente, informações sobre assunto previamente determinado, importando crime de responsabilidade a ausência injustificada desse chefe de Poder. Ao fazê-lo, porém, o art. 57 da Constituição capixaba não seguiu o paradigma da $\mathrm{CF}$, extrapolando as fronteiras do esquema de freios e contrapesos - cuja aplicabilidade

53 Art. 22. Compete privativamente à União legislar sobre: I - direito civil, comercial, penal, processual, eleitoral, agrário, marítimo, aeronáutico, espacial e do trabalho; [...]. (Grifo nosso.) 
é sempre estrita ou materialmente inelástica - e maculando o princípio da separação de Poderes. Ação julgada parcialmente procedente para declarar a inconstitucionalidade da expressão "Presidente do Tribunal de Justiça", inserta no $\S 2^{\circ}$ e no caput do art. 57 da Constituição do Estado do Espírito Santo. (ADI 2.911, Rel. Min. Carlos Britto, julgamento em 10.8.2006, Plenário, $D J$ de 2.2.2007.) (Grifo nosso.)

Uma ampliação ocorreu na Constituição da República por força da Emenda Constitucional 30 de 2000 que previu um crime de responsabilidade também para presidentes de tribunais em geral, regra repetida pela Emenda Constitucional 60 de 2009, estando hoje prevista no art. $100, \S 7^{\circ}$, da Constituição da República:

Art. $100, \S 7^{\circ}$. O Presidente do Tribunal competente que, por ato comissivo ou omissivo, retardar ou tentar frustrar a liquidação regular de precatórios incorrerá em crime de responsabilidade e responderá, também, perante o Conselho Nacional de Justiça. (Incluído pela Emenda Constitucional $\mathrm{n}^{\circ} 62$, de 2009.)
Vejamos agora a responsabilidade fiscal do Judiciário.

\section{A RESPONSABILIDADE FISCAL DO JUDICIÁRIO}

A ideia de responsabilidade fiscal ganhou relevo com o art. 169 da Constituição da República, ${ }^{54}$ o qual deu origem à Lei de Responsabilidade Fiscal, Lei Complementar Federal 101/2000, embora já fosse de nossa tradição o controle pelo Poder Legislativo de todos os demais Poderes, inclusive o Judiciário, com o auxílio do Tribunal de Contas em questões financeiras. ${ }^{55}$

A Lei de Responsabilidade Fiscal previu uma série de obrigações que devem ser observadas pelo Poder Judiciário de forma a gerir as verbas públicas a ele destinadas com responsabilidade.

A Lei não deixa dúvidas de sua aplicação ao Poder Judiciário ${ }^{56}$ e ela determina que deve haver o cumprimento de metas fiscais de resultado primário ou nominal, cabendo

54 Art. 169. A despesa com pessoal ativo e inativo da União, dos Estados, do Distrito Federal e dos Municípios não poderá exceder os limites estabelecidos em lei complementar.

55 CONTI, José Maurício. A Autonomia Financeira do Poder Judiciário. p. 112. São Paulo: Ministério Público, 2006.

56 LC 101/2000 Art. $1^{\circ}$ Esta Lei Complementar estabelece normas de finanças públicas voltadas para a responsabilidade na gestão fiscal, com amparo no Capítulo II do Título 
ao Judiciário limitar o empenho e a movimentação financeira segundo os critérios fixados pela lei de diretrizes orçamentárias, sob pena de isso ser feito pelo Poder Executivo..$^{57}$ Essa ingerência do Poder Executivo foi considerado inconstitucional pelo Supremo Tribunal Federal. ${ }^{58}$
Tal lei também limitou as despesas totais com pessoal em cada esfera de governo $^{59}$ e tanto no âmbito federal quanto estadual limitou as despesas do Judiciário a esse título em seis por cento da receita corrente líquida da União ou do Estado-membro ao qual pertença. ${ }^{60}$

VI da Constituição. [...] $\S 3^{\circ}$ Nas referências: I - à União, aos Estados, ao Distrito Federal e aos Municípios, estão compreendidos: a) o Poder Executivo, o Poder Legislativo, neste abrangidos os Tribunais de Contas, o Poder Judiciário e o Ministério Público; (grifo nosso). Sobre isso: NASCIMENTO, Carlos Valder do. In: MARTINS, Ives Gandra da Silva; NASCIMENTO, Carlos Valder do. (Organizadores) VV. AA.. Comentários à Lei de Responsabilidade Fiscal. 4. ed. p. 26. São Paulo: Saraiva, 2009.

57 LC 101/2000. Art. 9. Se verificado, ao final de um bimestre, que a realização da receita poderá não comportar o cumprimento das metas de resultado primário ou nominal estabelecidas no Anexo de Metas Fiscais, os Poderes e o Ministério Público promoverão, por ato próprio e nos montantes necessários, nos trinta dias subsequentes, limitação de empenho e movimentação financeira, segundo os critérios fixados pela lei de diretrizes orçamentárias. [...] $\S 3^{\circ}$ No caso de os Poderes Legislativo e Judiciário e o Ministério Público não promoverem a limitação no prazo estabelecido no caput, é o Poder Executivo autorizado a limitar os valores financeiros segundo os critérios fixados pela lei de diretrizes orçamentárias.

58 Liminar deferida para suspender o art. $9^{\circ}, \S 3^{\circ}$, na Adin 2238-5, ainda pendente de julgamento final. Disponível em: <http://www.stf.jus.br/portal/peticaoInicial/verPeticaoInicial.asp? base $=\mathrm{ADIN} \& \mathrm{~s} 1=2238 \&$ processo $=2238>$. Acessado em: 26.06 .2010 .

59 LC 101/2000 Art. 19. Para os fins do disposto no caput do art. 169 da Constituição, a despesa total com pessoal, em cada período de apuração e em cada ente da Federação, não poderá exceder os percentuais da receita corrente líquida, a seguir discriminados: I - União: 50\% (cinquenta por cento); II - Estados: 60\% (sessenta por cento); III - Municípios: $60 \%$ (sessenta por cento).

60 LC 101/2000 Art. 20. A repartição dos limites globais do art. 19 não poderá exceder os seguintes percentuais: I - na esfera federal: [...] b) $6 \%$ (seis por cento) para o Judiciário; [...] II - na esfera estadual: b) $6 \%$ (seis por cento) para o Judiciário; [...] $\S 1^{\circ}$ Nos Poderes Legislativo e Judiciário de cada esfera, os limites serão repartidos entre seus órgãos de forma proporcional à média das despesas com pessoal, em percentual da receita corrente líquida, verificadas nos três exercícios financeiros imediatamente anteriores ao da publicação desta Lei Complementar. $\S 2^{\circ}$ Para efeito deste artigo entende-se como órgão: [...] III - no Poder Judiciário: a) Federal, os tribunais referidos no art. 92 da Constituição; b) Estadual, o Tribunal de Justiça e outros, quando houver. $\S 3^{\circ}$ Os limites para as despesas com pessoal do Poder Judiciário, a cargo da União por 
Cabe ainda ao Presidente de cada Tribunal e demais membros de Conselho de Administração ou órgão decisório equivalente, conforme regimentos internos dos órgãos do Poder Judiciário, emitir relatório de gestão fiscal a cada quadrimestre, ${ }^{61}$ bem como prestar contas juntamente com o Poder Executivo. ${ }^{62}$

Essa última regra, prevista no art. 56 da Lei Complementar 101/2000 foi julgada inconstitucional pelo Supremo Tribunal Federal:

Medida cautelar em ação direta de inconstitucionalidade. Lei Complementar n. 101, de 4 de maio de 2000 (Lei de Responsabilidade Fiscal). Medida provisória n. 1.98022/2000. [...] Lei Complementar n. 101/2000. Vícios materiais. Cautelar deferida. [...] Art. 56, caput: norma que contraria o inciso II do art. 71 da Carta Magna, tendo em vista que apenas as contas do Presidente da República deverão ser apreciadas pelo Congresso Nacional. Art. 57: a referência a "contas de Poder", no $\S$ $2^{\circ}$ do art. 57, evidencia a abrangência, no termo "contas" constante do caput do artigo, daqueles cálculos decorrentes da atividade financeira dos administradores e demais responsáveis por dinheiros, bens e valores públicos, que somente poderão ser objeto de julgamento pelo Tribunal de Contas competente (inciso II do art. 71 da Constituição). (ADI 2.238-MC, Rel. p/ o ac. Min. Carlos Britto, julgamento em 9-8-07, Plenário, DJE de 12.9.08.) (Grifo nosso.)

Assim, o Poder Judiciário continua submetido ao julgamento técnico pelo Tribunal de Contas, como era antes da Lei de Responsabilidade Fiscal, e não apenas ao julgamento político pelo Poder Legislativo, como ocorre

força do inciso XIII do art. 21 da Constituição, serão estabelecidos mediante aplicação da regra do $\S 1^{\circ}$.

61 LC 101/2000 Art. 54. Ao final de cada quadrimestre será emitido pelos titulares dos Poderes e órgãos referidos no art. 20 Relatório de Gestão Fiscal, assinado pelo: [...] III - Presidente de Tribunal e demais membros de Conselho de Administração ou órgão decisório equivalente, conforme regimentos internos dos órgãos do Poder Judiciário; [...].

62 LC 101/2000 Art. 56. As contas prestadas pelos Chefes do Poder Executivo incluirão, além das suas próprias, as dos Presidentes dos órgãos dos Poderes Legislativo e Judiciário e do Chefe do Ministério Público, referidos no art. 20, as quais receberão parecer prévio, separadamente, do respectivo Tribunal de Contas. $\S 1^{\circ}$ As contas do Poder Judiciário serão apresentadas no âmbito: I - da União, pelos Presidentes do Supremo Tribunal Federal e dos Tribunais Superiores, consolidando as dos respectivos tribunais; II - dos Estados, pelos Presidentes dos Tribunais de Justiça, consolidando as dos demais tribunais. 
com o Chefe do Poder Executivo, o que foi estabelecido também em outro julgado:

[...] No âmbito das competências institucionais do Tribunal de Contas, o Supremo Tribunal Federal tem reconhecido a clara distinção entre: 1) a competência para apreciar e emitir parecer prévio sobre as contas prestadas anualmente pelo Chefe do Poder Executivo, especificada no art. 71, inciso I, CF/88;2) e a competência para julgar as contas dos demais administradores e responsáveis, definida no art. 71, inciso II, $\mathrm{CF} / 88$. Precedentes. Na segunda hipótese, o exercício da competência de julgamento pelo Tribunal de Contas não fica subordinado ao crivo posterior do Poder Legislativo. (ADI 3.715-MC, Rel. Min. Gilmar Mendes, 24.5.06. $)^{63}$

Encerrando essa questão lembramos que a Lei Federal 10.028/2000 criou uma série de tipos penais, inclusive crimes de responsabilidade, para punir o descumprimento do disposto na Lei Complementar 101/2000, criando também novas modalidades de infração administrativa a serem punidas pelo Tribunal de Contas, sub- metendo em todos os casos também o Judiciário e seus membros. ${ }^{64}$

\section{A RESPONSABILIDADE CIVIL DO MAGISTRADO}

Aqui discutimos a responsabilidade civil da pessoa física do magistrado, seja ministro, desembargador ou juiz no exercício da judicatura.

A esse respeito dispõe a Lei Orgânica da Magistratura Nacional, Lei Complementar Federal n. 35/1979:

Da Responsabilidade Civil do Magistrado

Art. 49. Responderá por perdas e danos o magistrado, quando:

I - no exercício de suas funções, proceder com dolo ou fraude;

II - recusar, omitir ou retardar, sem justo motivo, providência que deva ordenar o ofício, ou a requerimento das partes.

Parágrafo único - Reputar-se-ão verificadas as hipóteses previstas no inciso II somente depois que a parte, por intermédio do Escrivão, requerer ao magistrado que determine a providência, e este não lhe atender o pedido dentro de dez dias.

63 Nesse sentido: MILESKI, Hélio Saul. O Controle da Gestão Pública. p. 282. São Paulo: Revista dos Tribunais, 2003.

64 Sobre os crimes contra as finanças públicas vide: JESUS, Damásio E. Lei de Crimes contra as Finanças Públicas. In: MARTINS, Ives Gandra da Silva; NASCIMENTO, Carlos Valder do. (Organizadores) VV. AA.. Comentários à Lei de Responsabilidade Fiscal. 4. ed. p. 621 e seguintes. São Paulo: Saraiva, 2009. 
No que tange à possível prática de dano moral pelo magistrado, dispõe a mesma lei:

Art. 41. Salvo os casos de impropriedade ou excesso de linguagem o magistrado não pode ser punido ou prejudicado pelas opiniões que manifestar ou pelo teor das decisões que proferir. (Grifo nosso.)

Dessa forma, vê-se que o magistrado não goza de imunidade com relação à prática de danos morais por excesso ou impropriedade de linguagem, como ocorre com os parlamentares:

Constituição da República, Art. 53. Os Deputados e Senadores são invioláveis, civil e penalmente, por quaisquer de suas opiniões, palavras e votos. (Grifo nosso.)

Os parlamentares não praticam dano moral ou crimes contra a honra quando se manifestam no exercício da sua função, sendo essencial que tal manifestação tenha sido nesse exercício, tratando-se de prerrogativa irrenunciável como já afirmou o STF, ${ }^{65}$ sendo que essa garantia não se estende ao co-réu, conforme súmula 245 do STF. ${ }^{66}$
A respeito da responsabilidade civil do magistrado julgou o Supremo Tribunal Federal:

A autoridade judiciária não tem responsabilidade civil pelos atos jurisdicionais praticados. Os magistrados enquadram-se na espécie agente político, investidos para o exercício de atribuições constitucionais, sendo dotados de plena liberdade funcional no desempenho de suas funções, com prerrogativas próprias e legislação específica. Ação que deveria ter sido ajuizada contra a Fazenda Estadual - responsável eventual pelos alegados danos causados pela autoridade judicial, ao exercer suas atribuições -, a qual, posteriormente, terá assegurado o direito de regresso contra o magistrado responsável, nas hipóteses de dolo ou culpa. Legitimidade passiva reservada ao Estado. (RE 228.977, Rel. Min. Néri da Silveira, julgamento em 5.3.2002, Segunda Turma, $D J$ de 12.4.2002.) (Grifo nosso.)

O Supremo Tribunal Federal aí não disse que a Lei Orgânica da Magistratura Nacional não tem validade ou que o magistrado tenha algum tipo de imunidade, apenas aplicou o art. 37, § $6^{\circ}$ da Constituição da República que dispõe:

65 Inq. 510, Rel. Min. Celso de Mello, DJ 19/04/91.

66 Súmula $^{\circ} 245$. A imunidade parlamentar não se estende ao co-réu sem essa prerrogativa. 
Art. $37 \S 6^{\circ}$. As pessoas jurídicas de direito público, e as de direito privado prestadoras de serviços públicos responderão pelos danos que seus agentes, nessa qualidade, causarem a terceiros, assegurado o direito de regresso contra o responsável nos casos de dolo ou culpa.

Como se vê, o que o Supremo Tribunal Federal decidiu não é um privilégio para os magistrados, apenas afirmou que a ação deve ser proposta contra a pessoa jurídica de Direito Público à qual estiver ligado o magistrado, ressalvado o direito de regresso, regra que vale para todos os agentes públicos não protegidos por imunidades, como o são os parlamentares.

Outra modalidade de responsabilização que pode ser considerada civil, posto que discutida no âmbito do Judiciário em processo civil, é aquela prevista na Lei de Improbidade Administrativa, Lei Federal 8.429/1992, a qual todos os magistrados se submetem, integralmente.

\section{A RESPONSABILIDADE PENAL DO MAGISTRADO}

O magistrado responde penalmente como qualquer outro cidadão, inclusive por excesso de linguagem, como dito anteriormente, podendo praticar crime contra a honra, pois não tem a imunidade de que goza o parlamentar, como foi dito no item anterior.

A responsabilização penal do magistrado pode chegar à perda do cargo, como previsto pela Lei Orgânica da Magistratura Nacional ${ }^{67}$ e nos termos do Código Penal. ${ }^{68}$

O magistrado pode ser preso, como qualquer pessoa, por ordem escrita da autoridade judicial competente, ou seja, do Tribunal ou Órgão Especial competente para seu julgamento, como prevê o art. 33 da Lei Orgânica da Magistratura Nacional.

Também, como prevê a mesma lei, o magistrado poderá ser preso em flagrante de crime inafiançável, caso

67 Art. 26. O magistrado vitalício somente perderá o cargo (vetado): I - em ação penal por crime comum ou de responsabilidade; [...].

68 Art. 92. São também efeitos da condenação: (Redação dada pela Lei no 7.209, de 11.7.1984) I - a perda de cargo, função pública ou mandato eletivo: (Redação dada pela Lei $\mathrm{n}^{\circ}$ 9.268, de 1.4.1996) a) quando aplicada pena privativa de liberdade por tempo igual ou superior a um ano, nos crimes praticados com abuso de poder ou violação de dever para com a Administração Pública; (Incluído pela Lei nº 9.268, de 1.4.1996) b) quando for aplicada pena privativa de liberdade por tempo superior a 4 (quatro) anos nos demais casos. (Incluído pela Lei $\mathrm{n}^{\circ}$ 9.268, de 1.4.1996) [...] Parágrafo único - Os efeitos de que trata este artigo não são automáticos, devendo ser motivadamente declarados na sentença. (Redação dada pela Lei no 7.209, de 11.7.1984). 
em que a autoridade fará imediata comunicação e apresentação dele ao Presidente do Tribunal a que esteja vinculado. Hoje, com o advento da Lei 9.099/1995, qualquer pessoa praticamente não vai mais presa por crime afiançável.

Como ocorre com qualquer diplomado por faculdade superior da República e outras autoridades, o magistrado é recolhido à prisão especial, ou a sala especial de Estado-Maior, por ordem e à disposição do Tribunal ou do órgão especial competente, quando sujeito a prisão antes do julgamento final, nos termos do art. 33, III, da Lei Orgânica da Magistratura Nacional e o art. 295 do Código de Processo Penal.

Dessa forma, o magistrado não goza de imunidade quanto à prisão, como ocorre com o parlamentar:
Constituição Federal Art. $53 \S 2^{\circ}$ Desde a expedição do diploma, os membros do Congresso Nacional não poderão ser presos, salvo em flagrante de crime inafiançável. Nesse caso, os autos serão remetidos dentro de vinte e quatro horas à Casa respectiva, para que, pelo voto da maioria de seus membros, resolva sobre a prisão. (Redação dada pela Emenda Constitucional $\mathrm{n}^{\circ} 35$, de 2001.) (Grifo nosso.)

Como se vê, os parlamentares estão imunes das prisões penais provisórias, ou seja, prisão temporária ${ }^{69} \mathrm{e}$ prisão preventiva, ${ }^{70}$ diversamente dos magistrados.

O Presidente da República também tem imunidades penais de ordem formal.

Uma delas consiste no fato de que o Supremo Tribunal Federal não poderá

69 Lei 7.960/89, Art. $1^{\circ}$. Caberá prisão temporária: I - quando imprescindível para as investigações do inquérito policial; II - quando o indicado não tiver residência fixa ou não fornecer elementos necessários ao esclarecimento de sua identidade; III - quando houver fundadas razões, de acordo com qualquer prova admitida na legislação penal, de autoria ou participação do indiciado nos seguintes crimes: a) homicídio doloso (art. 121 , caput, e seu $\S 2^{\circ}$ ); b) sequestro ou cárcere privado (art. 148, caput, e seus $\S \S 1^{\circ} \mathrm{e}$ $2^{\circ}$ ); c) roubo (art. 157 , caput, e seus $\S \S 1^{\circ}, 2^{\circ}$ e $3^{\circ}$ ); d) extorsão (art. 158, caput, e seus $\S \S$ $1^{\circ}$ e $2^{\circ}$ ); e) extorsão mediante sequestro (art. 159 , caput, e seus $\S \S 1^{\circ}, 2^{\circ}$ e $3^{\circ}$ ); f) estupro (art. 213, caput, e sua combinação com o art. 223, caput, e parágrafo único); g) atentado violento ao pudor (art. 214, caput, e sua combinação com o art. 223, caput, e parágrafo único); h) rapto violento (art. 219, e sua combinação com o art. 223 caput, e parágrafo único); i) epidemia com resultado de morte (art. $267, \S 1^{\circ}$ ); j) envenenamento de água potável ou substância alimentícia ou medicinal qualificado pela morte (art. 270, caput, combinado com art. 285); 1) quadrilha ou bando (art. 288), todos do Código Penal; m) genocídio (arts. $1^{\circ}, 2^{\circ}$ e $3^{\circ}$ da Lei n. 2.889 , de $1^{\circ}$ de outubro de 1956), em qualquer de suas formas típicas; n) tráfico de drogas (art. 12 da Lei n. 6.368, de 21 de outubro de 1976); o) crimes contra o sistema financeiro (Lei n. 7.492, de 16 de junho de 1986).

70 Código de Processo Penal, Art. 312. A prisão preventiva poderá ser decretada como garantia da ordem pública, da ordem econômica, por conveniência da instrução 
receber a denúncia contra o Presidente da República por crimes comuns sem a autorização de dois terços dos membros da Câmara dos Deputados. Mas, se a denúncia for recebida, igual ao que ocorre no impeachment, o Presidente será afastado de suas funções, contudo aqui também se o feito não for julgado em cento $\mathrm{e}$ oitenta dias, ele retorna às funções, sem prejuízo do prosseguimento do feito. Deixou o STF claro que é possível processar o Presidente por crimes funcionais, mesmo no curso do mandato, se houver a mencionada autorização da Câmara. ${ }^{71}$

Também o Presidente não será preso, nem em flagrante de crime inafiançável, somente se sobrevier sentença condenatória, nas infrações comuns.

Já outra imunidade que parece ser material, mas não é, consiste no fato de que o Presidente, durante seu mandato, não pode ser responsabilizado por atos estranhos ao exercício de suas funções, conforme prevê o art. 86, $\S 4^{\circ}$, da CF.

A respeito disso disse o STF:

O que o art. $86, \S 4^{\circ}$, confere ao Presidente da República não é imunidade penal, mas imunidade temporária à persecução penal: nele não se prescreve que o Presidente é irresponsável por crimes não funcionais praticados no curso do mandato, mas apenas que, por tais crimes, não poderá ser responsabilizado, enquanto não cesse a investidura na presidência. Da impossibilidade, segundo o art. $86, \S 4^{\circ}$, de que, enquanto dure o mandato, tenha curso ou se instaure processo penal contra o Presidente da República por crimes não funcionais, decorre que, se o fato é anterior à sua investidura, o Supremo Tribunal não será originariamente competente para a ação penal, nem consequentemente para o habeas corpus por falta de justa causa para o curso futuro do processo. $\mathrm{Na}$ questão similar do impedimento temporário à persecução penal do Congressista, quando não concedida a licença para o processo, o STF já extraíra, antes que a Constituição o tornasse expresso, a suspensão do curso da prescrição, até a extinção do mandato parlamentar: deixa-se, no entanto, de dar força de decisão à aplicabilidade, no caso, da mesma solução, à falta de competência do Tribunal para, neste momento, decidir a respeito. (HC 83.154, Rel. Min. Sepúlveda Pertence, DJ 21/11/03.) (Grifo nosso.)

criminal, ou para assegurar a aplicação da lei penal, quando houver prova da existência do crime e indício suficiente de autoria. (Redação dada pela Lei n. 8.884, de 11.6.1994). 71 Inq 672-QO, Rel. Min. Celso de Mello, DJ 16/04/93. 
Portanto, se o Presidente praticar ou tiver praticado um crime comum não funcional, antes ou durante $o$ mandato, ${ }^{72}$ ele não poderá ser processado enquanto durar o seu mandato, sendo esse o significado do art. 86, $\S 4^{\circ}$, da Constituição Federal. Observe-se no acórdão citado que o STF já sinalizou no sentido da suspensão da prescrição, o que é essencial para evitar a impunidade.

O STF já se manifestou no sentido de que essa imunidade do Chefe de Estado, por ser uma exceção ao princípio republicano de igualdade entre todos, deve ser entendida de maneira restrita, não incluindo, portanto, os ilícitos civis, sejam de que natureza for, ${ }^{73}$ bem como só pode ser instituída pela Constituição, sendo vedada sua ampliação pela lei. ${ }^{74}$

Essas imunidades penais supramencionadas não se estendem a governadores e prefeitos, ficando restritas ao Presidente da República, como já decidiu o Supremo Tribunal Federal:

O Estado-Membro, ainda que em norma constante de sua própria Constituição, não dispõe de competência para outorgar ao Governador a prerrogativa extraordinária da imunidade à prisão em flagrante, a prisão preventiva e à prisão temporária, pois a disciplinação dessas modalidades de prisão cautelar submete-se, com exclusividade, ao poder normativo da União Federal, por efeito de expressa reserva constitucional de competência definida pela Carta da República. A norma constante da Constituição estadual - que impede a prisão do Governador de Estado antes de sua condenação penal definitiva - não se reveste de validade jurídica e, consequentemente, não pode subsistir em face de sua evidente incompatibilidade com o texto da Constituição Federal. (ADI 978, Rel. Min. Celso de Mello, DJ 24/11/95.) (Grifo nosso.)

O magistrado, tal como os parlamentares e o Chefe do Executivo, tem a prerrogativa de foro especial, como dispõe a Lei Orgânica da Magistratura Nacional:

Art. 33. Parágrafo único - Quando, no curso de investigação, houver indício da prática de crime por parte do magistrado, a autoridade policial, civil ou militar, remeterá os respectivos autos ao Tribunal ou órgão especial competente para o julgamento, a fim de que prossiga na investigação.

A respeito dessa prerrogativa de foro decidiu o Supremo Tribunal Federal:

72 Inq 672-QO, Rel. Min. Celso de Mello, DJ 16/04/93.

73 Inq 672-QO, Rel. Min. Celso de Mello, DJ 16/04/93.

74 ADI 1.021, Rel. Min. Celso de Mello, DJ 24/11/95. 
Crime de formação de quadrilha e peculato submetido ao Órgão Especial do Tribunal de Justiça em razão do privilégio de foro especial de que gozava o primeiro acusado. Preliminar de incompetência acolhida, em face de o referido réu já se encontrar aposentado. Alegação de contrariedade ao art. 96, III, da CF, propiciando a subtração da competência do TJRJ para julgar Juiz de Direito que tenha se aposentado, mas que anteriormente já teria praticado os ilícitos penais objeto do processo a ser julgado. Com o cancelamento da Súmula 394, pelo Plenário do $\mathrm{STF}$, cessa a competência especial por prerrogativa de função quando encerrado o exercício funcional que a ela deu causa, ainda que se cuide de magistrado. Precedente: Questão de Ordem no Inquérito n. 687-4. Com a aposentadoria cessa a função judicante que exercia e justificava o foro especial. (RE 295.217, Rel. Min. Néri da Silveira, julgamento em 8.4.02, $2^{\text {a }}$ Turma, DJ de 26.4.02.) (Grifo nosso.)

Assim, o magistrado perde a prerrogativa de foro ao se aposentar ou se por qualquer outro motivo deixar seu cargo, sendo que, em se tratando de magistrado estadual, a competência será do Tribunal de Justiça ao qual ele estiver vinculado, mesmo quando se tratar de crime federal:

Nos termos do art. 96, III, da Constituição, compete aos Tribunais de Justiça julgar os juízes estaduais, mesmo quando acusados de crimes de competência da Justiça Federal.
(HC 77.558, Rel. Min. Carlos Velloso, julgamento em 16.3.99, $2^{\mathrm{a}}$ Turma, $D J$ de 7.5.99.) (Grifo nosso.)

A única exceção à regra supra diz respeito à competência da Justiça Eleitoral.

Competência por prerrogativa de função do Tribunal de Justiça para julgar crime contra a honra de magistrado estadual em função eleitoral, praticado por Juiz de Direito (CF, art. 96, III). Firme a jurisprudência do Supremo Tribunal no sentido de que a única ressalva à competência por prerrogativa de função do Tribunal de Justiça para julgar juízes estaduais, nos crimes comuns e de responsabilidade, é a competência da Justiça eleitoral: precedentes. (RE 398.042, Rel. Min. Sepúlveda Pertence, julgamento em 2.12.03, $1^{\mathrm{a}}$ Turma, $D J$ de 6.2.04.) (Grifo nosso.)

\section{A RESPONSABILIDADE ADMINISTRATIVA DO MAGISTRADO PERANTE SUA PRÓPRIA CORREGEDORIA}

A Lei Orgânica da Magistratura Nacional exige no seu art. 21, V, que cada tribunal exerça a disciplina sobre os órgãos e serviços que lhes forem subordinados.

Tal atividade é chamada de corregedoria, tendo os tribunais sua Corregedoria Geral da Justiça para os magistrados de Primeiro Grau, res- 
pondendo os desembargadores perante o Órgão Especial ou o Pleno, onde não houver tal órgão.

À Corregedoria compete fornecer normas e orientações para o aprimoramento do serviço judiciário, não apenas lhe cabendo questões disciplinares, sendo que nessas últimas a Corregedoria age de ofício ou mediante provocação

A Lei Orgânica da Magistratura Nacional determina que "a atividade censória de Tribunais e Conselhos é exercida com o resguardo devido à dignidade e à independência do magistrado" (art. 40), sendo que, "salvo os casos de impropriedade ou excesso de linguagem, o magistrado não pode ser punido ou prejudicado pelas opiniões que manifestar ou pelo teor das decisões que proferir" (art. 41).

As penas previstas pela mesma lei em termos administrativos são:

1. Advertência (somente aplicável aos Juízes de primeira instância).

2. Censura (somente aplicável aos Juízes de primeira instância).

3. Remoção compulsória;

4. Disponibilidade com vencimentos proporcionais ao tempo de serviço.

5. Aposentadoria compulsória com vencimentos proporcionais ao tempo de serviço.

6. Demissão.
A pena de advertência deve ser aplicada reservadamente, por escrito, no caso de negligência no cumprimento dos deveres do cargo, já a de censura será aplicada na mesma forma, mas no caso de reiterada negligência no cumprimento dos deveres do cargo, ou no de procedimento incorreto, se a infração não justificar punição mais grave. O Juiz punido com a pena de censura não pode figurar em lista de promoção por merecimento pelo prazo de um ano, contado da imposição da pena.

A remoção e a disponibilidade, por serem mais severas, têm regras próprias:

Art. 45. O Tribunal ou seu órgão especial poderá determinar, por motivo de interesse público, em escrutínio secreto e pelo voto de dois terços de seus membros efetivos:

I - a remoção de Juiz de instância inferior;

II - a disponibilidade de membro do próprio Tribunal ou de Juiz de instância inferior, com vencimentos proporcionais ao tempo de serviço.

Essa regra foi alterada parcialmente pela Emenda Constitucional $45 / 2004$, a qual diminuiu o quorum para a aplicação de penas:

Art. 93. Lei complementar, de iniciativa do Supremo Tribunal Federal, disporá sobre o Estatuto da Magistratura, observados os seguintes princípios: [...] 
VIII - o ato de remoção, disponibilidade e aposentadoria do magistrado, por interesse público, fundarse-á em decisão por voto da maioria absoluta do respectivo tribunal ou do Conselho Nacional de Justiça, assegurada ampla defesa; (Redação dada pela Emenda Constitucional $\mathrm{n}^{\mathrm{o}}$ 45, de 2004) [...].

A pena de demissão, como previa a Lei Orgânica, poderia ser aplicada administrativamente a magistrados vitalícios nos casos previstos art. 26, I e II, ${ }^{75}$ e, nos casos de não vitalícios, por falta grave prevista no art. 56 da mesma lei. ${ }^{76}$ Os vitalícios podiam ser punidos pelas falhas previstas no art. 56, mas não com demissão.

Ocorre que a Constituição da República de 1988 afastou a possibilidade de a demissão ocorrer por decisão administrativa no caso de magistrados vitalícios:

Art. 95. Os juízes gozam das seguintes garantias:
I - vitaliciedade, que, no primeiro grau, só será adquirida após dois anos de exercício, dependendo a perda do cargo, nesse período, de deliberação do tribunal a que o juiz estiver vinculado, e, nos demais casos, de sentença judicial transitada em julgado; [...]. (Grifo nosso.)

Restou como a mais alta penalidade administrativa a aposentadoria compulsória, o que deu origem à Proposta de Emenda à Constituição $n^{\circ} 89$ de 2003, aprovada recentemente no Senado Federal onde se lê na justificação:

Recentemente a sociedade brasileira vivenciou uma situação absurda relacionada a medidas disciplinares adotadas em relação aos magistrados no âmbito do Poder Judiciário. A Corte Especial do Tribunal Regional Federal de Brasília aposentou, compulsoriamente, dois juízes, acusados de participação em esquema de vendas de sentenças a traficantes de drogas. Assistimos, estupefatos, a menciona-

75 Art. 26. O magistrado vitalício somente perderá o cargo (vetado): I - em ação penal por crime comum ou de responsabilidade; II - em procedimento administrativo para a perda do cargo nas hipóteses seguintes: a) exercício, ainda que em disponibilidade, de qualquer outra função, salvo um cargo de magistério superior, público ou particular; b) recebimento, a qualquer título e sob qualquer pretexto, de percentagens ou custas nos processos sujeitos a seu despacho e julgamento; c) exercício de atividade politico-partidária.

76 Art. 56. O Conselho Nacional da Magistratura poderá determinar a aposentadoria, com vencimentos proporcionais ao tempo de serviço, do magistrado: I - manifestadamente negligente no cumprimento dos deveres do cargo; II - de procedimento incompatível com a dignidade, a honra e o decoro de suas funções; III - de escassa ou insuficiente capacidade de trabalho, ou cujo proceder funcional seja incompatível com o bom desempenho das atividades do Poder Judiciário. 
da Corte proferir a sentença, segundo ela, de pena máxima aos acusados: a aposentadoria. Ora, é inegável que, neste caso, houve, isto sim, agraciamento e premiação, concedidos com proventos vitalícios a juízes acusados de corrupção. Tal fato contribui para a constatação de que, indubitavelmente, nossos magistrados dispõem, hoje, de garantias institucionais de feições extremamente paternalistas. $\mathrm{O}$ senso da moralidade nos indica que, neste caso específico, a pena administrativa mínima aceitável seria a perda do cargo. ${ }^{77}$ (Grifo nosso.)

Propondo a justificação que o Judiciário deve cortar na própria carne, pretende-se permitir a demissão de magistrados vitalícios por decisão administrativa do respectivo tribunal.

Ao autor do presente também repugna a aposentadoria compulsória como pena, pois dá mesmo uma sensação de prêmio àqueles que receberam e não honraram o fato de terem sido ungidos para o sacerdócio da Magistratura.

Ocorre que, em nosso entender, a solução seria acabar com essa "pena" pura e simplesmente, mas não revigorando norma do período ditatorial, como era a prevista na Lei Orgânica da Magistratura Nacional, pois isso equivaleria a derrubar a casa para acabar com os ratos.

Além disso, o Judiciário já corta na própria carne, pois como se vê no art. 95, I, os vitalícios podem ser demitidos sim, mas por sentença, ou seja, por ato judicial.

A vitaliciedade é uma garantia da cidadania de ter um juiz não sujeito a pressões e, portanto, com mais possibilidade de ser imparcial e não um privilégio odioso daquele que exerce o cargo de magistrado. ${ }^{78}$

Manoel Ferreira é incisivo ao dizer que "a independência do Judiciário é uma necessidade da liberdade individual", sendo que "as garantias referentes ao Judiciário como um poder visam essencialmente a estabelecer sua independência" com relação aos demais Poderes. Lembra o mestre ainda que "é característica desse poder, todavia, que esse órgão supremo propriamente [a instância superior e no último grau o $\mathrm{STF}]$ não comande os [magistrados] inferiores, cuja independência é, aliás, garantida também contra ele" (grifos nossos). ${ }^{79}$

77 Disponível em: <http://www.senado.gov.br/atividade/materia/detalhes.asp?p_cod_ mate $=64097>$. Acessado em: 26.08.2010.

78 Nesse sentido: MORAES, Alexandre de. Direito Constitucional. 19. ed. p. 463. São Paulo: Atlas, 2006.

79 Obra citada, p. 246-248. 
Em razão disso a vitaliciedade merece maior proteção, sendo evidente que um processo judicial é revestido muito mais dos atributos da ampla defesa e do contraditório que um procedimento administrativo pode ser.

Convém lembrar que tem a mesma garantia os Conselheiros e Ministros dos Tribunais de Contas e os membros do Ministério Público, pelas mesmas razões que as têm os magistrados.

Como as garantias do Judiciário são garantias dos direitos individuais, nos parece que a mencionada emenda à Constituição seria inconstitucional por ferir o art. $60, \S 4^{\circ}, \mathrm{IV}$, da Constituição da República. ${ }^{80}$

\section{A RESPONSABILIDADE ADMINISTRATIVA DO MAGISTRADO PERANTE O CONSELHO NACIONAL DE JUSTIÇA}

O Conselho Nacional de Justiça (CNJ) foi criado como controle externo do Judiciário pela Emenda Constitucional 45/2004 ${ }^{81}$ sob a alegação de que o Judiciário não tinha controle, o que não correspondia aos fatos, como se viu no decorrer da exposição deste trabalho, pois as regras abordadas até aqui são quase todas anteriores à mencionada emenda. Tal ocorrência apenas demonstra a correção de antiga ideia vigente no marketing político de que uma mentira repetida mil vezes se torna verdade.

A criação do Conselho causou grande resistência por parte dos magistrados, mas hoje tal não mais existe tanto, pois o Conselho Nacional de Justiça tem se mostrado muito útil na melhora do serviço judiciário.

Encerrando a discussão do cabimento ou não da existência do Conselho, o Supremo Tribunal Federal reconheceu a sua constitucionalidade:

Ação direta. EC 45/2004. Poder Judiciário. Conselho Nacional de Justiça. Instituição e disciplina. Natureza meramente administrativa. Órgão interno de controle administrativo, financeiro e disciplinar da magistratura. Constitucionalidade reconhecida. Separação e independência dos Poderes. História, significado e alcance concreto do princípio. Ofensa a cláusula constitucional imutável (cláusula pétrea). Inexistência. Subsistência do núcleo político do princípio, mediante preservação da função juris-

80 Art. $60[\ldots] \S 4^{\circ}$. Não será objeto de deliberação a proposta de emenda tendente a abolir: IV - os direitos e garantias individuais. [...].

81 Constituição da República, Art. 92. São órgãos do Poder Judiciário: I - O Conselho Nacional de Justiça; (Incluído pela Emenda Constitucional nº 45, de 2004). 
dicional, típica do Judiciário, e das condições materiais do seu exercício imparcial e independente. Precedentes e Súmula 649. Inaplicabilidade ao caso. Interpretação dos arts. $2^{\circ}$ e 60 , $\S 4^{\circ}$, III, da CF. Ação julgada improcedente. Votos vencidos. São constitucionais as normas que, introduzidas pela EC 45, de 8.12.2004, instituem e disciplinam o CNJ, como órgão administrativo do Poder Judiciário nacional. (ADI 3.367, Rel. Min. Cezar Peluso, julgamento em 13.4.2005, Plenário, $D J$ de 22-9-2006.)

Tal Conselho exerce atividade disciplinar sobre os magistrados, quando então tem poderes para aplicar sanções, como prevê a Constituição:

Art. 93. VIII - o ato de remoção, disponibilidade e aposentadoria do magistrado, por interesse público, fundar-se-á em decisão por voto da maioria absoluta do respectivo tribunal ou do Conselho Nacional de Justiça, assegurada ampla defesa; (Redação dada pela Emenda Constitucional $n^{\circ} 45$, de 2004)

Mas o Conselho não tem poder para determinar a demissão de magistrado, como fixou o Supremo Tribunal Federal:

Poder Judiciário. Conselho Nacional de Justiça. Competência. Magistratura. Magistrado vitalício. Cargo. Perda mediante decisão administrativa. Pre- visão em texto aprovado pela Câmara dos Deputados e constante do Projeto que resultou na EC 45/2004. Supressão pelo Senado Federal. Reapreciação pela Câmara. Desnecessidade. Subsistência do sentido normativo do texto residual aprovado e promulgado (art. 103-B, § $4^{\circ}$, III). Expressão que, ademais, ofenderia o disposto no art. 95, I, parte final, da CF. Ofensa ao art. $60, \S 2^{\circ}$, da CF. Não ocorrência. Arguição repelida. Precedentes. Não precisa ser reapreciada pela Câmara dos Deputados, expressão suprimida pelo Senado Federal em texto de projeto que, na redação remanescente, aprovada de ambas as Casas do Congresso, não perdeu sentido normativo. (ADI 3.367, Rel. Min. Cezar Peluso, julgamento em 13.4.2005, Plenário, $D J$ de 22.9.2006.)

Além disso, o Supremo Tribunal Federal reconheceu que a função disciplinar do CNJ tem caráter subsidiário devido ao princípio da autonomia do Judiciário, só podendo o Conselho atuar disciplinariamente contra magistrado se ocorrerem "situações anômalas e excepcionais registradas no âmbito dos tribunais em geral (hipóteses de inércia, de simulação investigatória, de procrastinação indevida e/ ou de incapacidade de atuação)". 82

Esse Conselho também tem baixado várias normas para regular a atividade do magistrado, o que o Supremo Tribunal Federal tem reconhe-

82 MS 28.801-MC/DF. Relator Ministro Celso de Melo. 02.08.2010. 
cido como válidas, ${ }^{83}$ mas o Supremo Tribunal Federal estabeleceu que esse tipo de órgão não pode ser recriado no âmbito dos Estados:

É inconstitucional a criação, por Constituição estadual, de órgão de controle administrativo do Poder Judiciário do qual participem representantes de outros poderes ou entidades. (Súmula 649.)

Tal posicionamento se deve, entre outros motivos, ao fato de que a Magistratura no Brasil é nacional, sendo que as divisões internas têm apenas relevância para fins de estabelecimento de competência.

\section{A RESPONSABILIDADE DO MAGISTRADO POR ERROS JURÍDICOS}

O Direito não é uma ciência exata, muito pelo contrário, assim, em termos jurídicos, soa no mínimo estranha a expressão "erro jurídico", a qual empregamos por razões retóricas.

Com efeito, muitas vezes aquilo que parece ser um "erro jurídico" pode na verdade ser uma interpretação criativa e de vanguarda, sendo comum o voto vencido tornar-se voto vencedor na medida em que o tempo avança.

A título de exemplo pode-se pinçar o que ocorreu com a união de homens e mulheres fora do casamento. Quando tais questões surgiram nos tribunais, essas uniões foram consideradas imorais e nenhum direito foi reconhecido como delas decorrente. Contudo, aos poucos, votos vencidos foram surgindo para reconhecer a existência de direitos e a situação evoluiu ao ponto de a união estável tornar-se constitucionalmente consagrada e socialmente respeitada, como é hoje.

Por isso tudo, no campo do Direito é mais correto se falar em ponto de vista ou opinião, sem os qualificativos de "certo" ou "errado", posto que eles não fazem sentido juridicamente falando.

Nesse sentido, a lição de Rui Barbosa lembrada pelo Ministro Paulo Brossard, no MS 214431/160 do Supremo Tribunal Federal:

[...] em todas as organizações políticas ou judiciais há sempre uma autoridade extrema para errar em ultimo lugar. O Supremo Tribunal Federal, não sendo infalível, pode errar, mas

83 MS 25.938, Rel. Min. Cármen Lúcia, julgamento em 24.4.2008, Plenário, DJE de 12.9.008 e ADC 12, Rel. Min. Carlos Britto, julgamento em 20.8.2008, Plenário, DJE de 18.12.2009. 
a alguém deve ficar o direito de errar por último, de decidir por último, de dizer alguma cousa que deva ser considerada como erro ou como verdade. Isto é humano [...].

Completou o Ministro no mesmo julgado com humildade: "O STF também erra. $\mathrm{E}$ errando em último lugar, só escassamente haverá meio de corrigir o erro, por meio de rescisória ou revisão criminal".

Como foi visto neste texto, o magistrado responde quando agir com dolo, fraude ou impropriedade de linguagem, não havendo e nem podendo haver punição advinda de interpretações da lei, mesmo que reputadas equivocadas, sob pena de se inviabilizar o funcionamento do Judiciário e retirar a independência do magistrado.

A importância dessa independência foi ressaltada pelo Ministro Celso de Mello:

[...] É que a independência judicial constitui exigência política destinada a conferir, ao magistrado, plena liberdade decisória no julgamento das causas a ele submetidas, em ordem a permitir-lhe o desempenho autônomo do "officium judicis", sem o temor de sofrer, por efeito de sua prática profissional, abusivas instaurações de procedimentos penais ou civis. A independência judicial - que tem, no art. 41 da LOMAN, um de seus instrumentos de proteção - traduz, no Estado democrático de direito, condição indispensável à preservação das liberdades fundamentais, pois, sem juízes independentes, não há sociedades nem instituições livres. (Inq 2699 QO, Relator(a): Min. CELSO DE MELLO, Tribunal Pleno, julgado em: 12.03.2009, DJe-084 DIVULG 07.05.2009, PUBLIC 08.05.2009 EMENT VOL-02359-01 PP-00136 RT v. 98, n. 886,2009 , p. 469-479.) (Grifo nosso.)

Como normalmente em um processo, há, pelo menos, duas partes em litígio e o juiz decide contra uma ou contra outra ou às vezes até contra as duas, pelo menos metade dos participantes do feito, se não todos, entenderão que o magistrado errou. Daí se percebe que punições por "erro jurídico" não tem o menor cabimento.

Para "erros jurídicos" o remédio é o recurso, não representação ou punição do magistrado.

\section{OUTRA \\ RESPONSABILIDADE DO JUDICIÁRIO}

O magistrado tem uma responsabilidade moral com as consequências de suas decisões, como bem demonstram as palavras sempre memoráveis do Desembargador Alves Braga:

As ordens dadas devem ser sempre razoáveis para que sejam cumpridas. Vem à lembrança o Rei do asteróide de que fala Saint Exupéry ao advertir o Pequeno Príncipe, que tinha direito 
de exigir obediência porque suas ordens eram razoáveis.

No exercício da judicatura deve ser presente o conselho do PADRE BERNARDES: "quem faz tudo o que pode, está muito perto de fazer o que não pode". DIOGO DE TEIVES, por sua vez, nos conselhos aos príncipes portugueses, advertia que só a virtude faz o soberano, lembrando das cautelas e limitações no uso do poder:

"Não queira fazer tudo quanto pode, Mas só quanto convém, quanto for justo,

E aqui de seu poder ponha limites, $E$ que entenda que também fica sujeito

às leis que ele mandou que se guardassem." 84

Assim, por exemplo, há julgados do STJ que disseram que as questões relativas às finanças públicas são irrelevantes em casos de pedidos de medicamentos, ${ }^{85}$ porém se espera do magistrado uma preocupação conglobante em suas decisões.

Não se espera que o magistrado preveja o futuro, mas sim que, como pessoa média, anteveja o que possa acontecer em virtude das decisões tomadas e realize suas ações sempre em prol do maior bem coletivo.

\section{A RESPONSABILIDADE ESTATAL POR ERROS JUDICIÁRIOS}

A responsabilidade estatal por ato de seus agentes é de regra objetiva, como dispõe a Constituição da República:

Art. $37, \S 6^{\circ}$. As pessoas jurídicas de direito público e as de direito privado prestadoras de serviços públicos responderão pelos danos que seus agentes, nessa qualidade, causarem a terceiros, assegurado o direito de regresso contra o responsável nos casos de dolo ou culpa.

Contudo, o Supremo Tribunal Federal estabeleceu uma ressalva em caso de atos de magistrados:

O Supremo Tribunal já assentou que, salvo os casos expressamente previstos em lei, a responsabilidade objetiva do Estado não se aplica aos atos de juízes. (RE 553.637-ED, Rel. Min. Ellen Gracie, julgamento em 4.8.2009, Segunda Turma, DJE de 25.9.2009.)

Tal decisão não afasta a possibilidade da responsabilidade subjetiva 
do Estado, nem a responsabilidade previamente estabelecida pela Constituição para quem sofrer dano por erro judiciário em processo penal:

Art. $5^{\circ}$. LXXV - o Estado indenizará o condenado por erro judiciário, assim como o que ficar preso além do tempo fixado na sentença; [...].

Nesse caso, a responsabilidade é objetiva, pois seria um dos casos previstos na decisão do Supremo Tribunal Federal em que esse tipo de responsabilidade se aplicaria.

\section{CONCLUSÕES}

Neste estudo observamos que o Poder Judiciário é uma função do Poder do Estado, este uno, indivisível e indelegável, diferenciando-se a função judicial da administrativa pelo método de trabalho e pela consequência, pois essa última produz coisa julgada, enquanto que a primeira não o faz, sendo que a Constituição de 1988 colocou o Judiciário como guardião e intérprete máximo dela mesma.

Vimos que a legitimidade democrática do Poder Judiciário, como ocorre com os demais poderes, decorre do sistema criado pelo Poder Constituinte para a composição de cada Poder, havendo em cada sistema maior ou menor participação popular, mas tendo os três a mesma validade, posto que oriundos da mesma fonte.
Continuamos o trabalho notando que o Judiciário, na sua atuação como legislador negativo, ou como legislador positivo, afeta as políticas públicas.

Vimos que o Supremo Tribunal Federal opta pela função judiciária como legislador negativo, porém, conforme lhe impôs o Poder Constituinte, não se furta em combater a negligência, exigindo o cumprimento da Constituição, principalmente em se tratando de normas autoaplicáveis cujo conteúdo seja possível extrair da Constituição e leis vigentes.

O Sistema constitucional brasileiro, além disso, tem paulatinamente se aproximado do sistema de Common Law, também denominado de "judge made Law", com a ressaltada importância que o precedente judicial vem recebendo ao longo dos anos.

Toda a lei processual, como estudamos, serve de limite à atuação do Poder Judiciário, além de normas especificamente previstas na própria Constituição como direitos fundamentais.

Definimos que a responsabilidade é a outra face da liberdade, sendo essa última um dos dois valores principais da democracia, o que nos autoriza a concluir que a responsabilidade é essencial em um sistema que se deseja democrático.

Daí podemos ver que o Judiciário tem as seguintes responsabilidades, inclusive com muito mais ênfase e muito menos prerrogativas que os demais Poderes em vários pontos: 
1. Responsabilidade política por crimes de responsabilidade.

2. Responsabilidade fiscal na administração da verba pública a ele destinada.

3. Responsabilidade civil de seus membros.

4. Responsabilidade penal de seus membros.

5. Responsabilidade administrativa perante seus tribunais.

6. Responsabilidade administrativa perante o Conselho Nacional de Justiça.

7. Outra responsabilidade consistente na constante obrigação de se preocupar com as consequências de suas decisões.

$\mathrm{Na}$ questão da responsabilidade vimos ainda que o magistrado não pode ser punido pelo que for reputado como "erro jurídico" porque isso não faria sentido.

Finalmente, constatamos que a responsabilidade estatal por erros judiciários não é objetiva, como normalmente ocorre, salvo no caso de expressa disposição legal, o que acontece com o erro judiciário penal, cuja indenização é constitucionalmente prevista.

Lembramos que a imprensa tem noticiado punições aplicadas a magistrados que não cumprem seu dever, o que é muito salutar para as instituições democráticas e para o prestígio do próprio Poder Judiciário. Porém, a imprensa nem sempre acompanha o desenrolar dos fatos, razão de muitas vezes ficar uma sensação de impunidade, a qual nem sempre estaria correspondendo à realidade.

\section{REFERÊNCIAS}

ARAÚJO, Luiz Alberto David; NUNES JÚNIOR, Vidal Serrano. Curso de Direito Constitucional. 11. ed. São Paulo: Saraiva, 2006. BAUM, Lawrence. A Suprema Corte Americana. Rio de Janeiro: Forense Universitária, 1987.

BULOS, Uadi Lammêgo. Curso de Direito Constitucional. São Paulo: Saraiva, 2007.

CAGGiANO, Monica Herman. A Jurisprudência Constitucional sobre Matéria Eleitoral. Disponível em: <http://www.mackenzie.br/fileadmin/Graduacao/FDir/ Artigos_2008/Controle_de_consti_2008_processo_constitucional_publ_mackenzie.pdf $>$. Acessado em: 26.08.2010.

CINTRA, Antônio C. de A.; GRINOVER, Ada Pellegrini; DINAMARCO, Cândido R. Teoria Geral do Processo. 11. ed. São Paulo: Malheiros, 1995. 
COLE, Charles D. Stare Decisis na Cultura Jurídica dos Estados Unidos. O Sistema de Precedente Vinculante do Common Law. In: Revista dos Tribunais. Fascículo Cível, Ano 87, V. 752, junho de 1998, p. 11-21.

CONTI, José Maurício. A Autonomia Financeira do Poder Judiciário. São Paulo: Ministério Público, 2006.

DALLARI, Dalmo de Abreu. O poder dos Juizes. 2. ed. São Paulo: Saraiva, 2002.

DI PIETRO, Maria Sylvia Z. Direito Administrativo. 19. ed. São Paulo: Atlas, 2006.

FERRAZ, Anna Cândida da Cunha. Processos Informais de Mudança da Constituição. Sem local: Max Limonad, 1986.

FERREIRA FILHO, Manoel Gonçalves. Curso de Direito Constitucional. 32. ed. São Paulo: Saraiva, 2006.

HOURQUEBIE, Fabrice. Sur l'émergence du Contre-pouvoir Juridictionnel sous La Vème République. Bruxelles: Bruylant, s.d.

JAMES, Philip S. Introduction to English Law. Twelfth Edition. London: Butteerworths, 1989.

JESUS, Damásio E. Lei de Crimes contra as Finanças Públicas. In: MARTINS, Ives Gandra da Silva; NASCIMENTO, Carlos Valder do. (Organizadores.) $V V$. $A A$.. Comentários à Lei de Responsa- bilidade Fiscal. 4. ed. São Paulo: Saraiva, 2009.

LEAL, Roger Stiefelmann. A Judicialização da Política. In: Revista dos Tribunais. Cadernos de Direito Constitucional e Ciência Política. Instituto Brasileiro de Direito Constitucional $\mathrm{n}^{\circ} 29$, outubro/dezembro de 1999, p. 230-237.

MARTINS, Ives Gandra da Silva; NASCIMENTO, Carlos Valder do. (Organizadores.) $V V$. $A A$.. Comentários à Lei de Responsabilidade Fiscal. 4. ed. São Paulo: Saraiva, 2009.

MENDES, Gilmar Ferreira; COELHO, Inocêncio Mártires; BRANCO, Paulo Gustavo Gonet. Curso de Direito Constitucional. São Paulo: Saraiva, 2007.

MILESKI, Hélio Saul. O Controle da Gestão Pública. São Paulo: Revista dos Tribunais, 2003.

MORAES, Alexandre de. Constituição do Brasil Interpreta e Legislação Constitucional. 7. ed. São Paulo: Atlas, 2007.

MORAES, Alexandre de. Direito Constitucional. 19. ed. São Paulo: Atlas, 2006.

NALINI, Renato. A Rebelião da Toga. Campinas: Millennium, 2006.

NOWAK, John E.; ROTUNDA, Ronald D. Constitutional Law. 4. ed. Saint Paul: West Publishing, 1991.

RIBEIRO, Antônio de Pádua. O Judiciário como Poder Político no Sé- 
culo XXI. In Boletim da Faculdade de Direito. Stvdia Ivridica 40, Colloqquia 2. "Portugal - Brasil Ano 2000. Tema Direito". Universidade de Coimbra. Coimbra: Coimbra, 1999, p. 11 a 26.

SABSAY, Daniel A.; ONAINDIA, José M. La Constitucion de los Argentinos. 3. ed. Buenos Aires: Errapar, 1994.

SILVA, José Afonso da. Curso de Direito Constitucional Positivo. 33. ed. São Paulo: Malheiros, 2010.

TÃNÃSECU, Elena Simina. On Responsibility in Public Law.
TAVARES, André Ramos. Curso de Direito Constitucional. 5. ed. São Paulo: Saraiva, 2007.

\section{SITES VISITADOS NA}

\section{INTERNET}

National Archives and Records Administration: http://www.archives.gov/. Senado Federal: www.senado.gov.br. Supremo Tribunal Federal: www.stf. jus.br.

Tribunal Superior Eleitoral: www.tse. jus.br. 